NBER WORKING PAPER SERIES

\title{
TRADE FLOWS AND EXCHANGE RATES: IMPORTERS, EXPORTERS AND PRODUCTS
}

\author{
Michael B. Devereux \\ Wei Dong \\ Ben Tomlin \\ Working Paper 26314 \\ http://www.nber.org/papers/w26314 \\ NATIONAL BUREAU OF ECONOMIC RESEARCH \\ 1050 Massachusetts Avenue \\ Cambridge, MA 02138 \\ September 2019
}

We thank Patrick Alexander, Jason Allen, James Chapman, Alex Chernoff, Geoff Dunbar, Doireann Fitzgerald, Youngmin Park, Alexander Ueberfeldt, and seminar and conference participants for their comments. We also thank Beiling Yan, Claudiu Motoc and Danny Leung at Statistics Canada for their help in preparing and interpreting the data, and Bassirou Gueye and Graeme Westwood for their excellent research assistance. The results have been institutionally reviewed to ensure that no confidential information is revealed. The views expressed in this paper are those of the authors and no responsibility for them should be attributed to the Bank of Canada or the National Bureau of Economic Research. Devereux thanks the Social Sciences and Humanities Research Council of Canada for financial support.

NBER working papers are circulated for discussion and comment purposes. They have not been peer-reviewed or been subject to the review by the NBER Board of Directors that accompanies official NBER publications.

(C) 2019 by Michael B. Devereux, Wei Dong, and Ben Tomlin. All rights reserved. Short sections of text, not to exceed two paragraphs, may be quoted without explicit permission provided that full credit, including $\odot$ notice, is given to the source. 
Trade Flows and Exchange Rates: Importers, Exporters and Products

Michael B. Devereux, Wei Dong, and Ben Tomlin

NBER Working Paper No. 26314

September 2019

JEL No. F1,F4

\begin{abstract}
$\underline{\text { ABSTRACT }}$ relationships, which can impact long-run flows.

Michael B. Devereux

Department of Economics

University of British Columbia

997-1873 East Mall

Vancouver, BC V6T 1Z1

CANADA

and NBER

mbdevereux@gmail.com

Wei Dong

Bank of Canada

wdong@bank-banque-canada.ca

Ben Tomlin

Bank of Canada

Ottawa

btomlin@bankofcanada.ca
\end{abstract}

Using highly-disaggregated transaction-level trade data, we document the importance of new firm-level trade partner relationships and the addition of new products to existing relationships in driving long-run import flows. Moreover, we find that these margins are sensitive to movements in the exchange rate. We rationalize these findings in a model of international trade with endogenous matching between heterogenous importers and exporters. Simulations of the model highlight a new channel through which exchange rate movements can affect trade-through the short-run formation of new trade relationships and the range of products traded within 


\section{Introduction}

At the most fundamental level, international trade takes place between an exporting firm and an importing firm for a given product. Although a truism, developing a better understanding of this tripartite relationship may be key for understanding trade flows. A long-standing literature has explored the effects of trade shocks on the intensive and extensive margins of trade in terms of firms and products traded (Krugman, 1979; Baldwin, 1988; Baldwin and Krugman, 1989; Dixit, 1989; and Melitz, 2003), highlighting persistent effects stemming from the entry and exit of firms and products in international markets. However, when considering the full buyer-seller-product relationship in a trade setting, there are a number of other margins - such as the establishment of new relationships between importers and exporters and adjustments along the product margin within relationships - that have heretofore received little attention.

In this paper, we examine the role of new buyer-seller relationships and changes in the set of products within relationships in driving aggregate trade flows, and we show that adjustments along these margins emanating from exchange rate shocks can have persistent trade effects. To do so, we make use of highly disaggregated customs data on Canadian imports to first detail several stylized facts about market concentration and trade relationships. We show that (i) the Canadian import market is dominated by a relatively small number of foreign exporters and domestic importers; (ii) larger firms on both sides of trade transactions have more trade partners, products and products per trade partner; (iii) new buyer-seller relationships and the addition of new products to existing relationship are the primary drivers on long-run import flows; and (iv) the formation and destruction of new relationships, as well as the range of products traded within a buyer-seller relationships, are sensitive to movements in exchange rates.

We then rationalize these findings in a model of international trade with endogenous matching between heterogenous importers and exporters. In addition, each exporter produces multiple products, which allows for adjustments along the product dimension within trade relationships. With a reasonable calibration, the model can replicate the empirical findings above, capturing both the heterogeneity and the granularity in individual buyer-seller-product relationships. Moreover, the model suggests that a domestic currency appreciation is associated with a significant increase in firm-to-firm matches and the number of products traded within relationships. There are fixed costs associated with the formation of new relationships and the addition of new products to existing relationships, which appreciations of the importer currency can help overcome. Consequently, even transitory movements in the exchange rate can have long-run effects by affecting these margins in the short run.

The customs data we use cover the universe of Canadian commercial imports from September 2002 to June 2008. For this paper we use a subset of nine broad product categories that have complete information on quantities shipped and the total value of the shipment, along with some 
other vital information, and account for roughly 40 percent of the value of imports in any given year $]^{1}$ A key feature of this dataset is that it allows us to identify both the Canadian importer and foreign exporter involved in each transaction, along with a narrow product identifier. With this, we start by measuring the degree of concentration in the Canadian import market and find that the top 1 percent of foreign exporters account for over 50 percent of imports into Canada. At the same time, the top 1 percent of Canadian importers account for over 60 percent of the import market. These large firms also have more trade partners than smaller firms, with exporters in the top quintile of sales to Canada having three times more trade partners than those in the bottom quintile, and large importers having over 17 times more partners.

A unique finding of this paper is the importance of new relationships and the addition of new products to existing relationships in determining long-run import flows. Short-run flows are dominated by continuous buyer-seller-product relationships, accounting for over 87 percent of quarterly imports. However, as newly formed relationships accumulate and those that survive grow, they make up an increasing share of imports flows. This is also true for new products added to existing relationships. In both cases, these new relationships start small, making up a limited portion of overall trade flows - approximately 12 percent of the quarterly value of imports - but dominate flows after several years. We show that new buyer-seller relationships established over the 2003 to 2007 period and the addition of new products to existing relationships within the same period account for over 53 percent of the value of imports in 2007. Therefore, the short-run formation of these new buyer-seller-product relationships is important for long-run import flows.

The link between relationship formation and import flows suggests that trade shocks, such as exchange rate fluctuations, may have important long-run macro implications by influencing short-run firm-level dynamics. Empirically, we find that appreciations of the Canadian dollar (CAD) are associated with an increase in the number of relationships for importers and the number of products per buyer-seller relationship. Logit regressions support this finding because appreciations of the CAD are related to an increase in the probability of an importer adding a new trade partner and adding a new product to an existing relationship. This provides some initial evidence that transitory trade shocks can have long-term effects by influencing the formation of new firm and product relationships.

These findings guide the development of a parsimonious model of the imported goods market with endogenous buyer-seller matching and product choice. In the model, sellers choose the measure of buyers with whom they interact, the measure of product varieties to offer to each of these buyers, and the price for each variety sold to a given buyer. Buyers combine the endogenously determined range of intermediate inputs into a unique final good, which they sell

\footnotetext{
${ }^{1}$ These data were previously used in Devereux, Dong and Tomlin (2017). See that paper for more details on the data.
} 
to domestic consumers. Both the establishment of relationships and the addition of products to relationships involve fixed costs, so the model generates a set of cut-off points for the addition of new trade relationships and products within relationships, which also depend on the exogenous productivity of both the exporter and importer. In equilibrium, the import market is dominated by a small number of exporters and importers, and larger firms have more trade partners and products per partner, as in the data. Moreover, simulations of the model show that short-run adjustments along the different buyer-seller-product margins are similar to what is observed in the data.

Next, we explore the model's response to an appreciation of the destination-market currency. Adjustments within continuous buyer-seller-product relationships dominate the response in terms of import value, but, with multi-product exporters and endogenous matching, firms in the model also respond by adding new trade partners and products within existing relationships. This shows up in significant increases in the shares of these margins in total buyer-seller-product transactions. We consider this to be the short-run response to an exchange rate shock, but with the existence of fixed costs associated with establishing these new relationships, there may be long-run effects even when the currency returns to its pre-shock level. This analysis remains a work in progress.

Our paper is the first to highlight these specific mechanisms through which exchange rates affect trade flows. There are similarities to earlier work by Baldwin (1988) and Baldwin and Krugman (1989), which feature hysteresis in trade resulting from large exchange rate shocks. These papers, however, focus on the entry and exit of exporters. Newly exporting firms are often small firms to begin with, and it can take time for them to grow and have an impact on aggregate trade flows. Our focus is on the margins relating to buyer-seller relationships and the products within these relationships, which can involve large, established firms on both sides of the trade and are shown to be very important in the aggregate within a couple of years. Moreover, the fixed costs associated with adding a trade partner or product can be lower than the costs associated with entering a new market or exporting for the first time. Therefore these margins are likely more sensitive to movements in exchange rates, making their analysis more germane to typical exchange rate fluctuations that may not necessarily be large enough to induce significant firm entry and exit.

This paper also builds on the literature that examines the extensive margin of trade in terms of the countries (Helpman, Melitz and Rubenstein, 2008) and firms involved in trade (Melitz, 2003; Eaton, Kortum and Kramarz, 2011) as well as the products being traded (Broda and Weinstein, 2006; Chaney, 2008). It diverges from these papers by focusing not on new firms or products in a given country, but rather on firm-level relationships, where, within the traditional intensive margin (continuing firms or products within a country), there are relationship-extensive margins - the establishment of new relationships and adjustments in the products traded within 
relationships. Our decomposition of the Canadian import data suggests that these margins are important in the long run and are influenced by trade shocks in the short run.

Increasing availability of firm-level trade data sets where firms on both sides of transactions can be identified in some way has led to a burgeoning literature on firm-to-firm relationships and the importance of the relationships in driving trade. Bernard, Moxnes and Ulltveit-Moe (2018) use Norwegian export data to document several facts about buyers and sellers across markets and develop a model to explore the implications of importer and exporter heterogeneity on export growth. Eaton et al. (2016) develop a two-sided search and match model of trade and fit it to Colombian import data to study how entry of exporters and reductions in search costs affect import flows. Kramarz, Martin and Mejean (2016) use French export data to show how network structure and granularity magnify aggregate fluctuations.

Blum, Claro and Horstmann (2010) establish a number of facts about trade between firms in Argentina and Chile. Monarch and Schmidt-Eisenlohr (2017) quantify the value of trade relationships in U.S. import data and then explore the aggregate implications of the relationships. Heise (2018) also makes use of the U.S. import data to explore the relationship between exchange rate pass-through and the length of buyer-seller relationships and provides evidence that passthrough increases as relationships age. Like these papers, we use highly disaggregated data where the identity of the firms on both sides of transactions is known. Where this paper differs is that we use the data to highlight a new mechanism through which exchange rates can affect long-run trade flows.

Beyond our results on the effects of exchange rates, the findings in this paper may apply more broadly, speaking to the effects of trade shocks and short-run versus long-run trade elasticities (see Ruhl, 2008; Drozd, Kolbin and Nosal, 2017). Any large shock that disrupts the formation of new trade relationships and the addition of products within a relationship can have long-lasting effects that may not be apparent in the short run. Key here is the identification of relationship formation and product adjustment as being important in the long run and being sensitive to aggregate shocks.

The remainder of the paper proceeds as follows. Section 2 describes the data used and the key empirical findings relating to importer, exporter and product relationships. The model is presented in section 3, along with a detailed exploration of its properties. Section 4 explores the response of the model to exchange rate shocks and examines the mechanisms that exist in the short run that influence long-run dynamics. Section 5 concludes. 


\section{Data and Stylized Facts on International Trade}

\subsection{Transaction-level import data}

In this section, we document a number of facts about international trade between importers, exporters and products. In order to do so, we use data from the Canadian Border Services Agency (CBSA) that contain information on every commercial import/shipment into Canada from September 2002 to June 2008. The data, collected by the CBSA and housed at Statistics Canada, contain information on the total value of each shipment (in the currency in which it was paid for as well as the Canadian-dollar value), the number of units shipped, the 10-digit Harmonized Commodity Description and Coding System (HS) product code for the good, the country from which the good originated (the country of origin) and the country from which the good was finally exported directly to Canada.

Critically for our analysis, the data set also has an importing firm identifier and an exporting firm/vendor identifier - that is, we know, for each transaction, the good coming into Canada as well as the firms on both sides of the transaction. The scrambled (for confidentiality) importing firm identifier allows us to track a single Canadian buyer over time and is associated with the province in which the buyer is located. On the exporter side, the identifier is built from the company name provided in the customs sheet, which is linked in the cross-section and over time based on a name-matching algorithm developed by researchers at Statistics Canada.

While the data are reported at the individual transaction level, most statistics reported in this paper are at a monthly, quarterly or annual frequency. In each case, the unit of observation is a buyer-seller-product relationship, where a product is defined at the six-digit HS (HS6) code level. As a result, when we talk about products entering and exiting buyer-seller relationship, it is clearly a new type of product rather than a variation on a product, which could be the case if we defined a product at the eight- or 10-digit HS code level.

As in Devereux, Dong and Tomlin (2017), we use a segment of the data that comprises nine broad product categories representing a wide range of goods and accounting for approximately 40 percent of Canadian imports in any given month. The nine product groupings or sectors are presented in Table 1 along with the number of observations at the transaction level. Overall, there are about 68 million transaction-level observations, just over 71,000 unique importers and 297,100 unique exporters. In any given year in the data, there are approximately 40,000 importers and 121,00 exporters.

In the data set, there is a variable that identifies whether the two firms involved in a transaction are affiliated (intra-firm trade). For the findings below, we do not eliminate these observations. In some cases, it is more informative to keep these observation - when, for example,

examining overall market share and concentration levels - and in general, the results differ little 
Table 1: Product Categories

\begin{tabular}{lcc}
\hline & HS Code & \# of Observations \\
\cline { 2 - 3 } Vegetable products & $07-14$ & $6,401,302$ \\
Food and beverage & $16-22$ & $3,363,866$ \\
Chemical products & $28-35$ & $4,793,851$ \\
Textiles & $50-60$ & $8,397,023$ \\
Apparel & $61-62$ & $6,162,182$ \\
Footwear & 64 & 906,285 \\
Metal products & $72-81$ & $20,354,196$ \\
Industrial machinery & 84 & $12,054,290$ \\
Consumer electronics & 85 & $5,494,637$ \\
\hline Total & & $67,927,538$ \\
\hline
\end{tabular}

Note: HS Code refers to the range of two-digit Harmonized Commodity Description and Coding System products included in the broad product category. The \# of Observations is the number of buyer-seller-product transactions in the data, and this can include multiple buyer-seller-product transactions in a given month.

with and without these observations. Therefore we opt to preserve them in order to provide a clearer picture of the aggregate outcomes.

\subsection{Findings on buyer-seller-product relationships}

In this subsection, we describe a number of facts relating to buyer-seller-product relationships in the Canadian import market. We start by looking at the degree of market concentration, then further explore the trade networks and relationships between buyer and sellers. We then use these facts as a guide to develop a model of international trade with multi-product exporters in the next section. Important findings presented in this subsection are that a large fraction of long-run import flows can be accounted for by new buyer-seller relationships and new products being introduced into existing buyer-seller relationships as well as that these margins are sensitive to trade shocks in the short run.

Finding 1: The import market is dominated by a small number of importers and exporters

A key characteristic of the Canadian import market is that it is dominated by a relatively small number of foreign exporters and domestic importers. Figure 1(a) shows that the top 1 percent of importers (in terms of value of imports in 2007) - approximately 400 importing firmsaccount for almost 62 percent of the value of all imports within the nine product categories, and the top 10 percent of account for 92 percent of imports. On the other side, Figure 1(b) shows that the top 1 percent of exporters - approximately 1,200 firms - account for 52 percent of Canadian imports and the top 10 percent account for 87 percent of the import market. 
Figure 1: Importer and Exporter Share of the Canadian Import Market by Percentile Bin, 2007

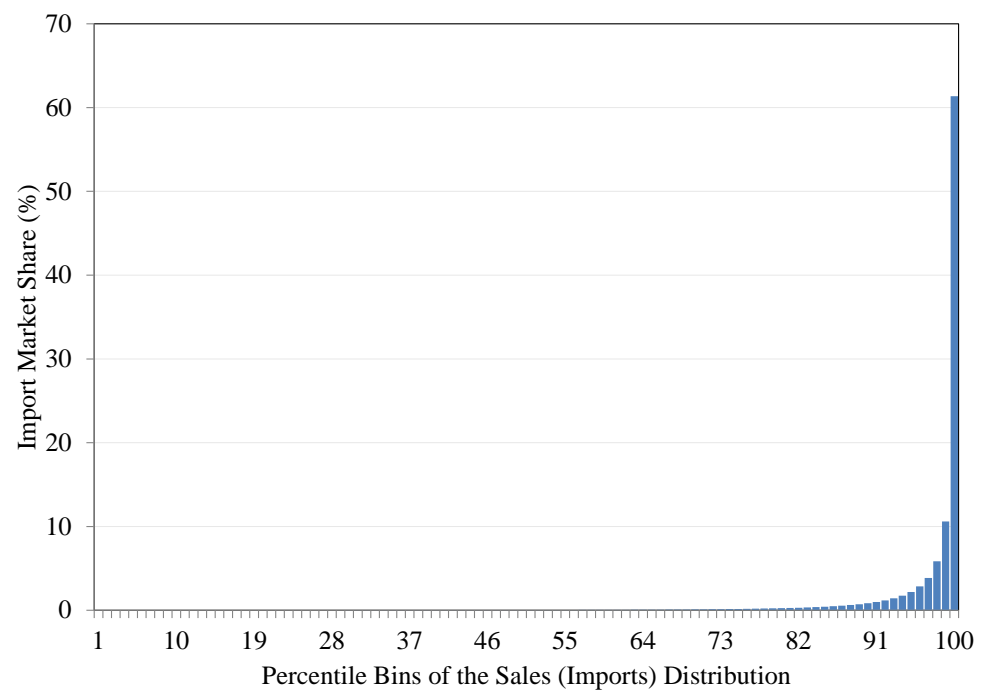

(a) Importers

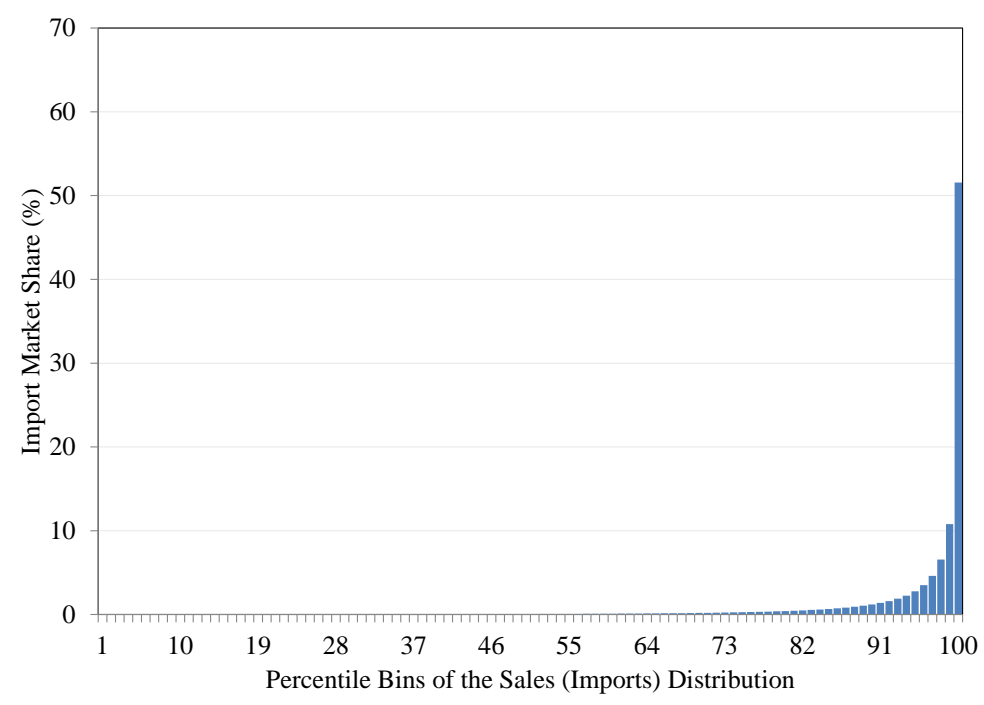

(b) Exporters

Note: Panel (a) presents the share of import value accounted for by importing firms in each percentile of the import-value distribution. Panel (b) presents the share of Canadian imports accounted for by exporting firms in each percentile of the import-value distribution.

Moreover, import flows are largely determined by importers and exporters that have many trade partners. Using Norwegian export data, Bernard, Moxnes and Ulltveit-Moe (2018) find that trade flows are dominated by transactions involving exporters that are matching with many trade partners and that exports by exporters with only one foreign trade partner make up a small portion of trade flows. We replicate the Bernard, Moxnes and Ulltveit-Moe (2018) exercise for our data and present the results in Table 2. We see that trade relationships where the importer and foreign exporter only trade with each other within the Canadian import market (one-to-one 
matches) account for 1.68 percent of all importer-exporter connections in 2007, and only 0.25 percent of the value of trade. Similarly, many-to-one matches - where the exporter has many Canadian trade partners, but the importer only trades with that one exporter - account for a small percentage of matches (3.90 percent) and value (0.68 percent). The majority of trade is accounted for by one-to-many matches - where the importer is a multi-trade-partner firm, but the exporter only trades with one importer in the Canadian market - and many-to-many matches - where both the importer and exporter have multiple trade partners. Together, these types of interactions account for 94.42 percent of importer-exporter matches and 99.07 percent of the value of trade in 2007.

Table 2: Types of Matches Between Importers and Exporters

\begin{tabular}{lcccc}
\hline & One-to-One & Many-to-One & One-to-Many & Many-to-Many \\
\cline { 2 - 5 } Share of total number of matches $(\%)$ & 1.68 & 3.90 & 36.04 & 58.38 \\
Share of total trade value $(\%)$ & 0.25 & 0.68 & 32.97 & 66.10 \\
\hline
\end{tabular}

Note: The calculations in this table are analogous to Table 8 in Bernard et al. (2018). The results are for 2007 data. One-to-one matches are where the importer and exporter are trading only with each other. Many-to-one matches are where the exporter has many Canadian trade partners, but the importer has only the one exporter match. One-to-many is when the importer is importing from many exporters, but the exporter is trading only with that importer. Many-to-many matches are where both the importer and the exporter have many trade partners.

These results highlight the difference in using exporter-based data, as Bernard, Moxnes and Ulltveit-Moe (2018) do, versus using importer-based data, as we do. While both data sets suggest that trade is dominated by exporters and importers that have many trade partners (many-to-many transactions), the exporter-based data of Bernard, Moxnes and Ulltveit-Moe (2018) suggest that many-to-one matches also play an important role in trade flows (and one-toone and one-to-many matches make up a small portion of trade). In our importer-based data, many-to-one matches play a small role in Canadian imports, but one-to-many are an important component of trade. The difference in results is likely because, using the exporter-based data, Bernard, Moxnes and Ulltveit-Moe (2018) observe the full set of trade partners of the exporter, but not of the foreign importer. Conversely, we observe the full set of trade partners of the importer, but not of the foreign exporter. Combining our results in Table 2 with those in Bernard et al. (2018) suggests that a complete data set with all transactions between all firms in all countries would likely show that trade is solely dominated by many-to-many matches; that is, trade between firms (importers and exporters) that have multiple trade partners. We take this into account in the model presented below. 
Finding 2: Larger firms have more trade partners, products, and products per trade partner

This set of facts builds on what is described above, but shows that larger firms (in terms of the value of imports/exports to Canada) have more trade partners, import/export more products, and trade more products per trade partner than smaller firms. Table 3 reports that an importer in the first quintile of the of the import-value distribution trades with an average of 1.2 exporters, whereas an importer in the top quintile has an average of 17.2 trade partners. On the exporter side, an average firm in the first quintile has 1.1 trade partners, and one in the fifth quintile has 3.6 Canadian trade partners. For a more detailed look at this, Figure 2 presents the number of trade partners by market share percentile for importers and exporters in each of the nine product categories. The pattern is evident in all product categories: larger firms have more trade partners. Note that importers (exporters) may well be importing (exporting) goods from several of the product categories at the same time, so this figure is understating the actual number of trade partners per firm. Nevertheless, this more disaggregated view of the trade partner distribution is important to see so that we know that the patterns shown in Table 3 are not coming simply from differences in product market structure.

Table 3: Number of Trade Partners by Quintile of Import Market Share (2007)

\begin{tabular}{|c|c|c|c|c|}
\hline & Importers & & Exporters & \\
\hline Quintile & $\begin{array}{c}\text { Mean \# of } \\
\text { Trade Partners }\end{array}$ & S.D. & $\begin{array}{c}\text { Mean \# of } \\
\text { Trade Partners }\end{array}$ & S.D. \\
\hline 1 & 1.2 & 0.7 & 1.1 & 0.4 \\
\hline 2 & 1.7 & 1.3 & 1.2 & 0.7 \\
\hline 3 & 2.6 & 2.5 & 1.5 & 1.1 \\
\hline 4 & 4.5 & 4.5 & 1.9 & 2.1 \\
\hline 5 & 17.2 & 61.4 & 3.6 & 6.3 \\
\hline
\end{tabular}

Figure 3 presents the average numbers of products per importer and exporter by market share percentile for each of the nine product categories. Again, a clear pattern emerges: the larger the importing (exporting) firm, in terms of the value of trade, the more unique HS6 products it imports (exports). While the majority of importers import one or two products regardless of the sector, a significant amount of heterogeneity exists across sectors at the top end of the distribution. For example, importers in the top percentile in the apparel sector import an average of 62 unique HS6 products, whereas those in the food and beverage sector import about 16 products. Similarly for exporters, those in the top percentile of the apparel sector export an average of 24 products to Canada, while those in the food and beverage sector export about 5 products.

Finally, Figure 4 shows that larger firms import/export more products per trade partner. For example, importers at the lower end of the distribution in the apparel sector import, on 
Figure 2: Number of Trade Partners by Market Share Percentiles, 2007
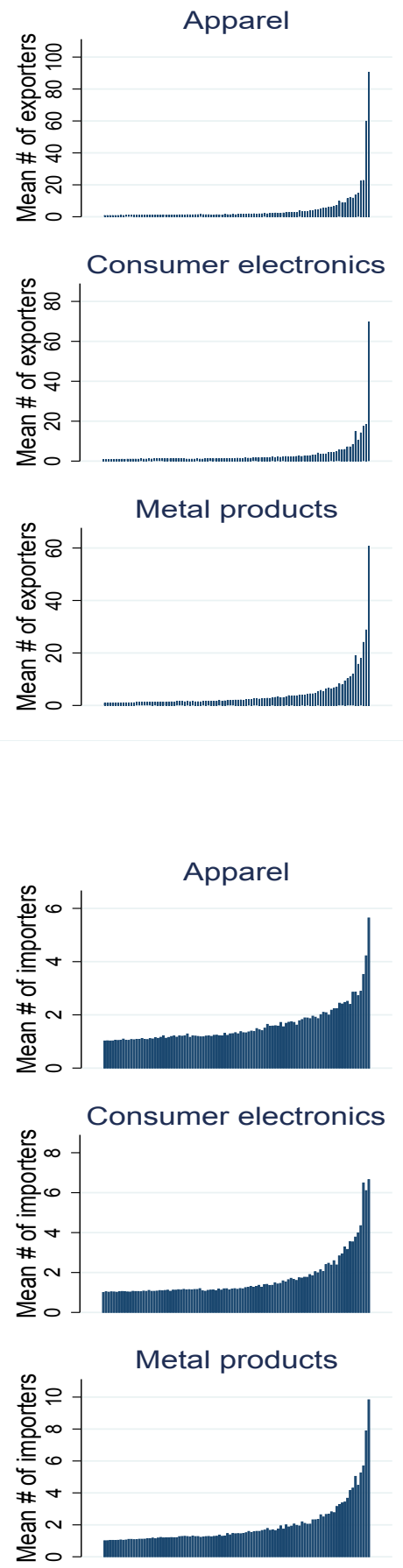

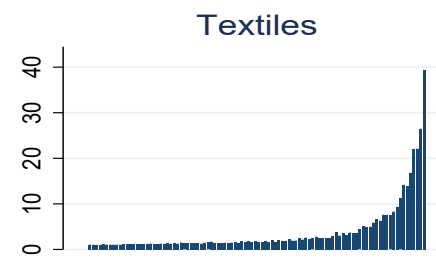

Food and beverage

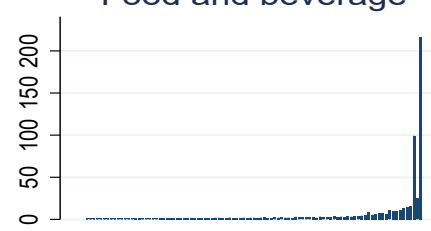

Shoes

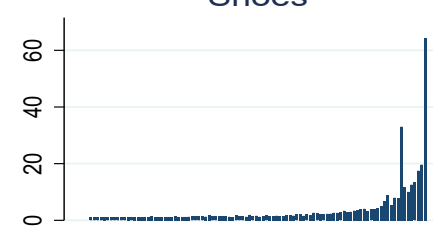

(a) Importers

Textiles

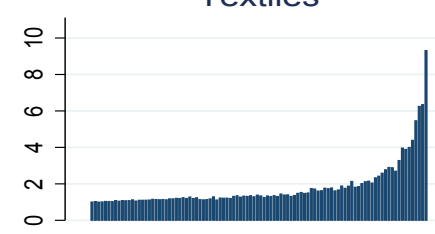

Food and beverage

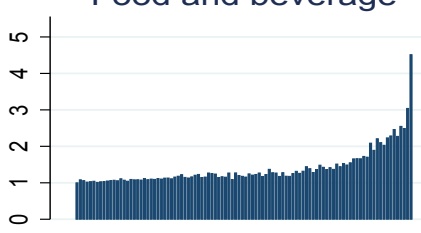

Shoes

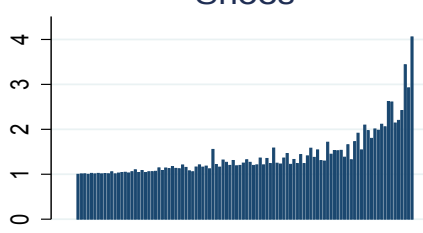

Chemical products

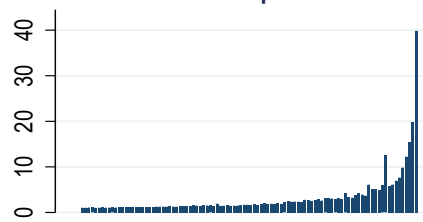

Machinery
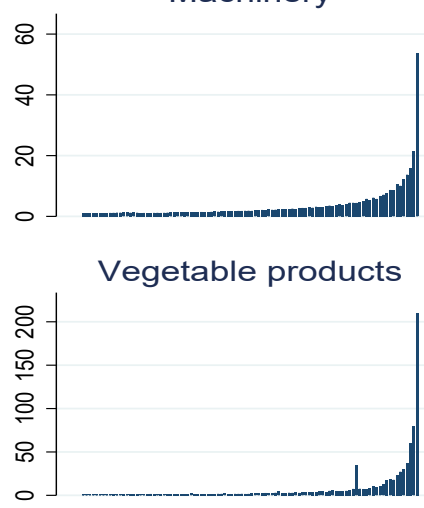

(b) Exporters

Note: Panel (a) presents the average number of trade partners per importer within percentile bins based on the total value of imports in 2007. Panel (b) presents the average number of trade partners in Canada per exporter within percentile bins based on the total value of Canadian imports in 2007. 
Figure 3: Number of Products by Market Share Percentiles, 2007
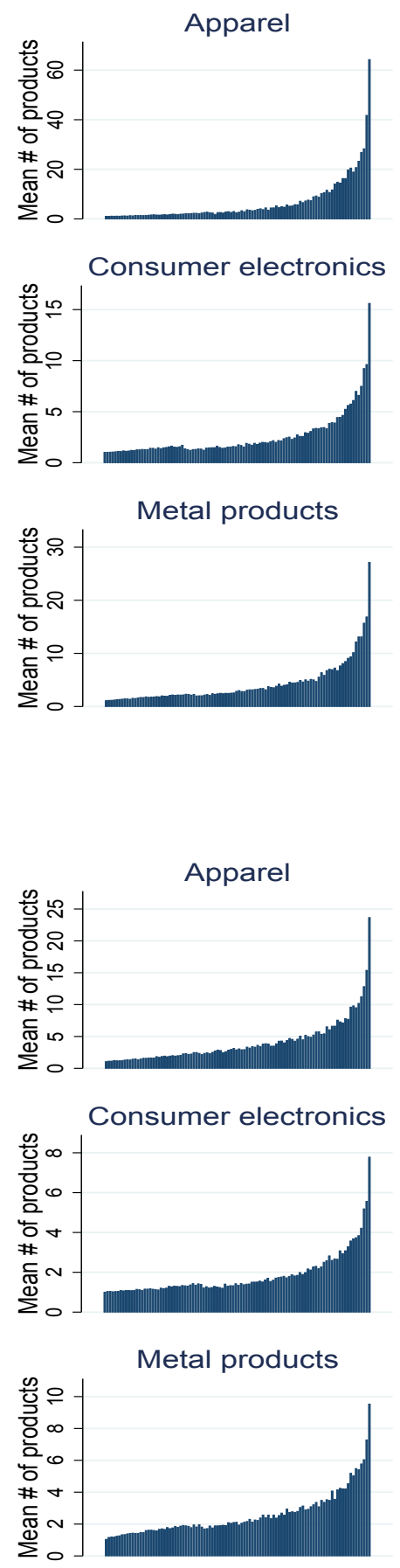

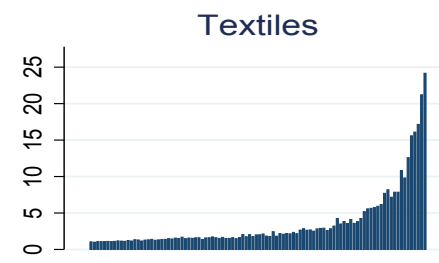

Food and beverage

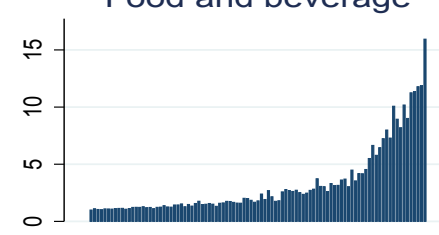

Shoes

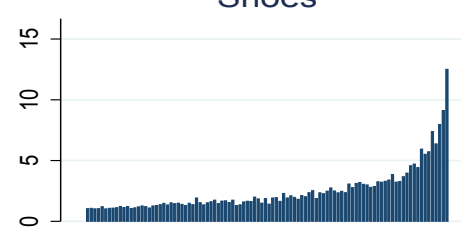

(a) Importers
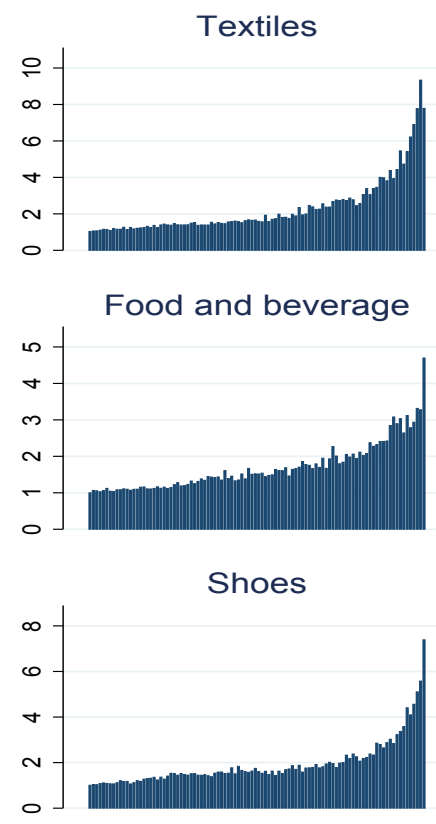

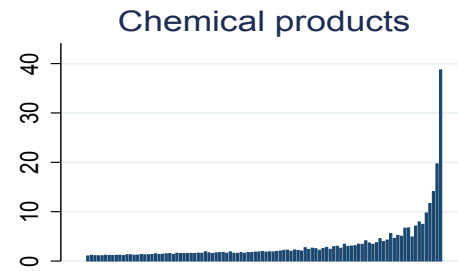

Machinery

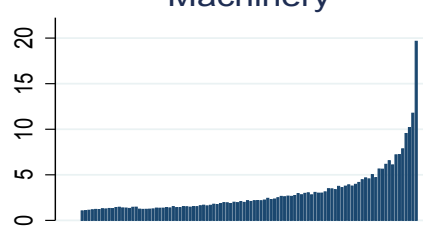

Vegetable products

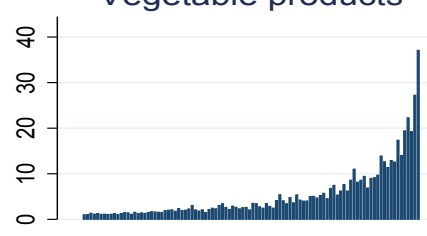

(b) Exporters

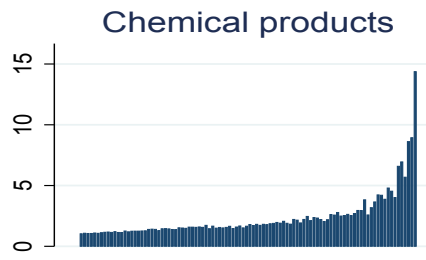

Machinery

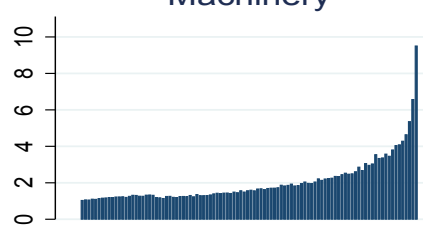

Vegetable products

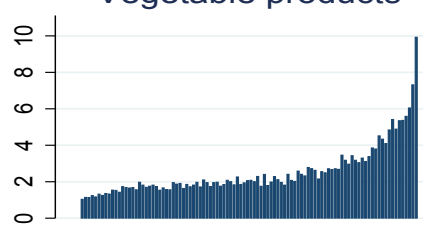

Note: Panel (a) presents the average number of products imported by importers within percentile bins based on the total value of imports in 2007. Panel (b) presents the average number of products exported to Canada by exporters within percentile bins based on the total value Canadian imports in 2007. 
average, one product per trade partner. Those firms at the top end of the distribution purchase almost eight products from each trade partner. A similar pattern is observed in all the other product categories. For firms exporting apparel items to Canada, those in the bottom end of the distribution are sending on average 1 product to each trade partner, and those at the top end of the distribution are exporting about 12 products per trade partner. Again, this pattern is evident across all other product categories for exporters..$^{2}$ As mentioned above, firms may be involved in multiple product markets at the same time, so the product and products-per-tradepartner counts in Figures 3 and 4 may understate the actual firm-level counts. Calculations similar to Table 3 but for products and products-per-partner show that the positive relationship between market share products and products-per-trade partner hold when not conditioning on product category.

Finding 3: New buyer-seller matches and the introduction of new products into existing buyerseller relationships are important contributors to import flows in the long run

Each period, trade flows evolve along a number of margins in the buyer-seller-product space. Traditionally, trade flows are divided into intensive and extensive margins of trade, where these margins are defined at the firm or product level (see, for example, Eaton, Kortum and Kramarz, 2004, Bernard et al., 2009, and Bernard, Redding and Schott, 2011). That is, the introduction of a new firm or product into international trade markets constitutes the extensive margins, whereas the continued involvement of a firm or trading of a product contributes to the intensive margin. In line with the former definition, we begin by defining what we call the importer extensive margin, which refers to import flows coming from firms importing for the first time. The remainder is the importer intensive margin and in line with previous research $3^{3}$

We divide the importer-intensive margin into three further margins that dissect the buyerseller-product relationship, and all of these margins are conditional on the buyer having imported before. The first is what we call the buyer-seller extensive margin, which refers to imports coming from a new match between a Canadian importer and foreign exporter (it may include the first time an exporter is observed, but the importer was already importing). The second is the product

\footnotetext{
${ }^{2}$ The results in Figure 4 understate the true degree of heterogeneity in the number of products per trade partner, especially at the top end of the market share distribution, where large firms often have a few trade partners with whom they trade many products and many firms with whom they trade only a few (or even one) products. When constructing Figure 4, we first take the mean number of trade partners per relationship for each firm and then take the mean within each percentile of the market share distribution. This process can mask the fact that there are many large firms that have relationships with many products and therefore the necessary conditions for the within-relationship product margin to matter in the aggregate, which is relevant to what we explore below.

${ }^{3}$ Our focus on the importer for defining the extensive margin is based on the fact that we observe the full set of trade operations for that importer, so we can clearly identify when they have become active as an importer. For exporters, we only observe the exporting activities to Canada and therefore cannot identify when they became exporters. For this reason, our decompositions are based on the importer.
} 
Figure 4: Number of Products per Trade Partner by Market Share Percentiles, 2007
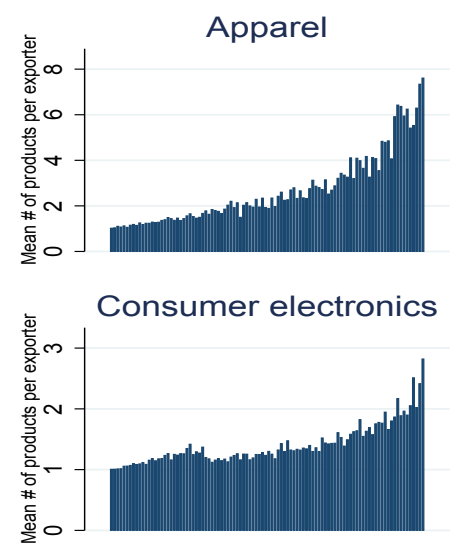

Metal products
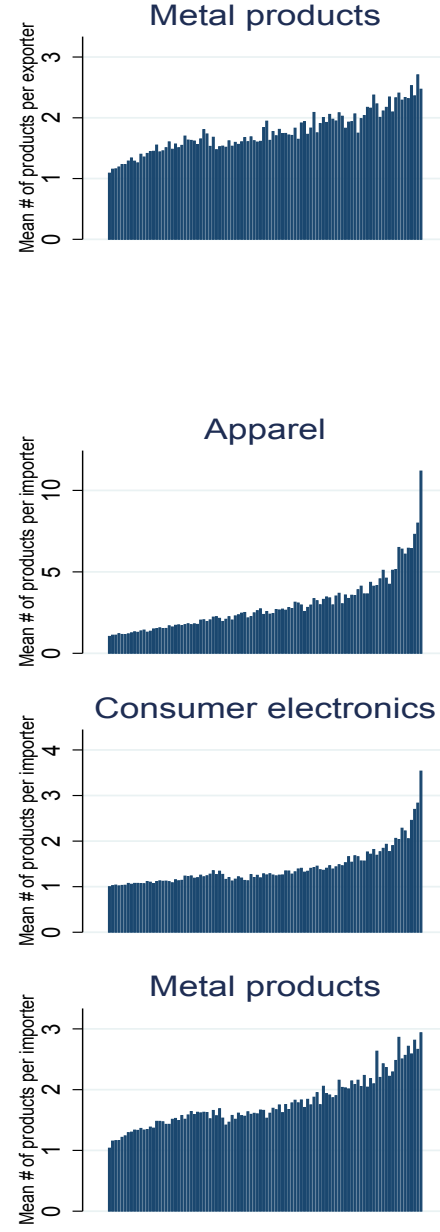

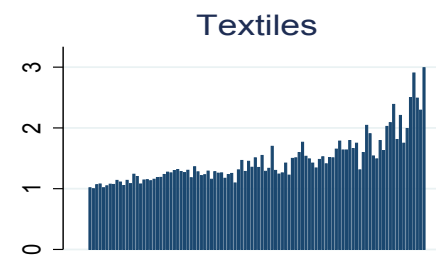

Food and beverage

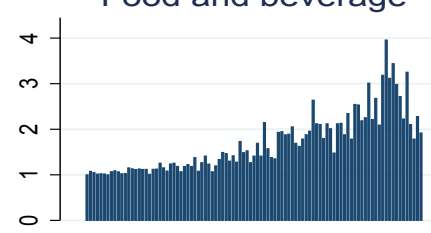

Shoes

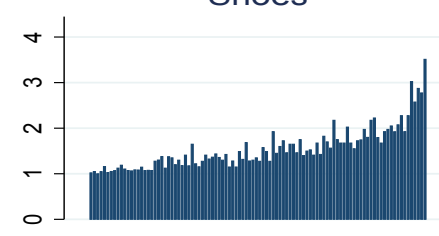

(a) Importers
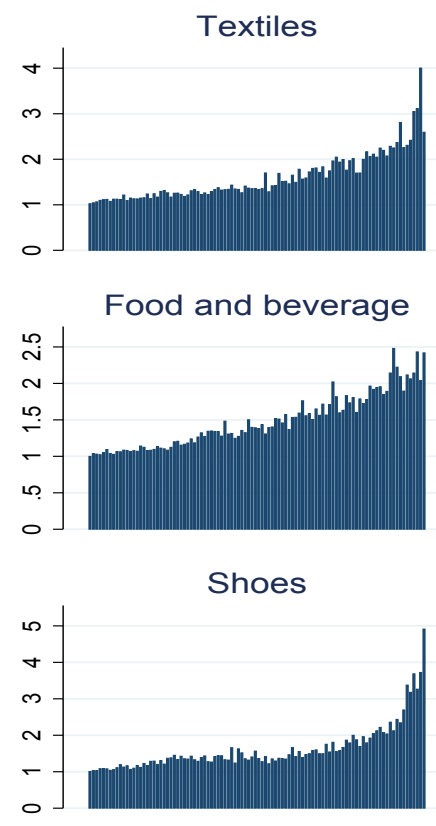

(b) Exporters

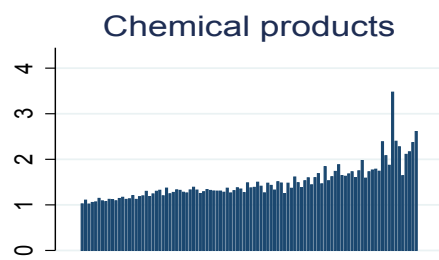

Machinery

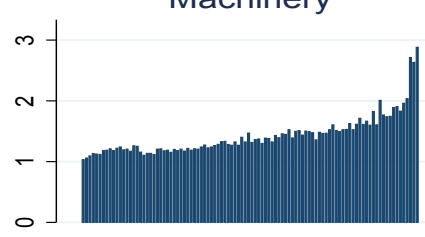

Vegetable products

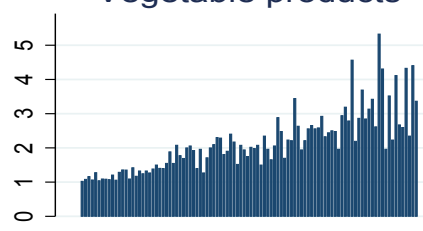


extensive margin, which refers to the introduction of a new product into an existing buyer-seller relationship. Finally, there is the pure intensive margin, which is continuous trade between a buyer and seller for a given product (that is, the buyer-seller-product relationship observed at a point in time time existed previously). The first two sub-margins (hereafter jointly referred to as the interior margins) will offer added insight into the evolution of trade flows beyond the traditional extensive and intensive margins of trade.

We begin by looking at the contribution of these different margins to quarterly import flows, or what we call short-run trade flows. In order to do this, we identify the margins by tracking buyer-seller-product relationships in a given quarter over the previous year. That is, a quarterly buyer-seller-product transaction is flagged as being part of the importer extensive margin if that importer did not import any product (from any exporter) in the previous four quarters. If the importer/buyer imported at some point over the last four quarters, but the buyer-seller match is new in the current quarter, the import flows associated with this buyer-seller match are assigned to the buyer-seller extensive margin. When a new product is introduced into a buyer-seller match that already existed some time in the previous four quarters, these buyer-seller-product import flows are assigned to the product extensive margin. Lastly, when a buyer-seller-product relationship existed at some point in the previous four quarters, the current quarter flows are assigned to the pure intensive margin.

Panel A of Table 4 reports the contributions of the different margins to quarterly trade in terms of the share of buyer-seller-product transactions and share of the value of import flows. The calculations are done for each quarter and then averaged over all quarters. The importer extensive margin plays a small role in determining quarterly import flows, accounting for less than 3 percent of transactions and less than 1 percent of value. The buyer-seller and product extensive margins are more important in terms of transactions - accounting for roughly 25 and 16 percent of transactions, respectively - but their share of total value is much smaller (both are below 10 percent). This indicates that, while there are many of these interactions, their average value is relatively small. Finally, the pure intensive margin accounts for the vast majority of short-run import transactions and value, at roughly 57 and 88 percent, respectively. Therefore, in the short run, the pure intensive margin dominates because more transactions are between firms that are in continuous product relationships, and these relationships are relatively large in terms of value.

Over time, newly established relationships (in terms of trade partners or products within existing relationships) may accumulate, and those that survive may grow and play a more important role in the long run. We explore the long-run contributions of these margins by first converting the data into annual buyer-seller-product transactions. We then take all of the relationships in 2007 and look back to see whether they existed in 2003. If the importer was operating in 2007, but not in 2003, all of the importer's 2007 transactions are assigned to the 
Table 4: Short- and Long-Run Contributions of Buyer-Seller-Product Margins to Import Flows

Panel A: Short-Run Contributions (quarterly, 2003:3-2008:2)

Importer intensive

\begin{tabular}{lccccc} 
& $\begin{array}{c}\text { Importer } \\
\text { extensive }\end{array}$ & & $\begin{array}{c}\text { Buyer-seller } \\
\text { extensive }\end{array}$ & $\begin{array}{c}\text { Product } \\
\text { extensive }\end{array}$ & $\begin{array}{c}\text { Pure } \\
\text { intensive }\end{array}$ \\
\cline { 2 - 2 } \cline { 5 - 6 } Share of total trade transactions (\%) & 2.7 & & 24.6 & 15.9 & 56.8 \\
Share of total trade value (\%) & 0.7 & & 8.1 & 3.4 & 87.9 \\
\hline
\end{tabular}

Panel B: Long-Run Contributions (annual, 2007 compared with 2003)

Importer intensive

\begin{tabular}{lccccc} 
& $\begin{array}{c}\text { Importer } \\
\text { extensive }\end{array}$ & $\begin{array}{c}\text { Buyer-seller } \\
\text { extensive }\end{array}$ & $\begin{array}{c}\text { Product } \\
\text { extensive }\end{array}$ & $\begin{array}{c}\text { Pure } \\
\text { intensive }\end{array}$ \\
\cline { 2 - 3 } \cline { 6 - 7 } Share of total trade transactions (\%) & 15.5 & & 41.0 & 29.4 & 14.1 \\
Share of total trade value (\%) & 7.7 & & 31.1 & 22.6 & 38.6 \\
\hline
\end{tabular}

Note: To calculate the short-run contributions in Panel A, we identify the contribution of each margin to quarter $t$ import flows by looking back over the previous four quarters. For example, if an importer did not import in the previous four quarters, its quarter $t$ imports are assigned to the importer extensive margin. In Panel B, the margins are identified for 2007 only, by looking back to 2003. For example, if a firm imports in 2007, but did not import in 2003, its 2007 imports are assigned to the importer extensive margin. To separate the long-run contributions of the buyer-seller and product extensive margins, when a buyer-seller relationship is formed after 2003, all products traded within that relationship in the year it is formed are assigned to the buyer-seller extensive margin. Products added to the relationship after the year it was formed are assigned to the product extensive margin.

importer extensive margin. For importers that were importing the same HS6 product from the same partner in 2003 and 2007, their 2007 transactions are allocated to the pure intensive margin. The remainder is accounted for by the buyer-seller and product margins. To split them, we track the buyer-seller-product relationship over the post-2003 period. When a new relationship is formed in the 2004-2007 period, we assign the products traded at the time the relationship is formed to the buyer-seller extensive margin. When a new product is added to an old relationship sometime over this period - and this includes relationships that may have been formed post-2003 but before the new product is added - we attribute this to the product extensive margin.

Panel B in Table 4 presents the results from this decomposition, which we refer to as the long-run contributions of the different margins. Interestingly, after four years, the buyer-seller and product extensive margins become dominant, accounting for a combined 70 percent of transactions and over 50 percent of the value of imports. Individually, the buyer-seller extensive margin accounts for 41 percent of annual transactions and 31 percent of import value, while the product extensive margin accounts for 29 and 23 percent of transactions and value, respectively..$^{4}$

\footnotetext{
${ }^{4}$ The buyer-seller and product extensive margins could be split a number of ways. If the products traded at the time a buyer-seller relationship is formed, and all subsequent products added to the relationship, are allocated
} 
While the pure intensive margin is still the biggest individual category, its share of imports (both in transaction and value) has declined significantly from its short-run shares.

The increasing shares of the interior margins from the short run to the long run may be driven by the accumulation of new relationships over time and/or growth in the surviving relationships. To explore this further, we first calculate the contributions to total 2007 import value coming from adjustments along these margins in each year. Figure 5 shows that the relationships formed in 2004 account for roughly 6 percent of imports in 2007, while those formed in 2005, 2006 and 2007 account for approximately 6, 8 and 10 percent of 2007 imports, respectively. For the product extensive margin, the contribution of new products added to existing relationships in 2004 to the value of imports is about 2 percent; it is 3, 4 and 14 percent for those added in 2005, 2006 and 2007, respectively. This finding suggests that the accumulation of new relationships is important in explaining the long-run shares of the interior margins because older cohorts play less of a role in determining current flows than later cohorts but nevertheless contribute to current flows through the accumulation of past cohorts.

Within cohorts, many newly formed relationships do not survive. Figure 6 shows that only 25 percent of the new buyer-seller relationships established in 2004 survive in to 2005, and, by 2007, only 13 percent remain active. Similarly for new products added to existing relationships in 2004, 29 percent are still traded within these relationships in 2005, and only 15 percent remain in 2007.

These high attrition rates, along with the fact the shares of the 2004 cohorts presented in Figure 5 remain close to the short-run value shares presented in Panel A of Table 4, suggest that either larger new relationships are more likely to survive or those that survive have a high growth rate or both. Growth rates of different relationships are difficult to calculate for a number of reasons (including attrition within the sample and partial-year effects), but Figure 7 shows that larger new relationships are more likely to survive into subsequent years. A newly formed relationship in the top quintile of the 2004 new-relationship value distribution (see Panel a), has a 41 percent chance of surviving in to 2005 and 21 percent change of surviving until at least 2007. A new relationship in the bottom quintile only has a 12 and 6 percent chance of surviving to 2005 and 2007, respectively. Similarly for new products introduced into existing relationships (see Panel b), where new products in the top quintile of the new-product-into-existing-relationships value distribution have a higher chance of surviving than those in the lower quintiles.

to the buyer-seller extensive margins, the contribution of the buyer-seller extensive margin to 2007 import value is closer to 40 percent, and the product extensive margin is closer to 15 percent. We chose the decomposition presented above to highlight the role of the product extensive margin, but some of this could easily be attributed to the buyer-seller extensive margin. 
Figure 5: Long-Run Contribution of the Buyer-Seller and Product Extensive Margins by Year

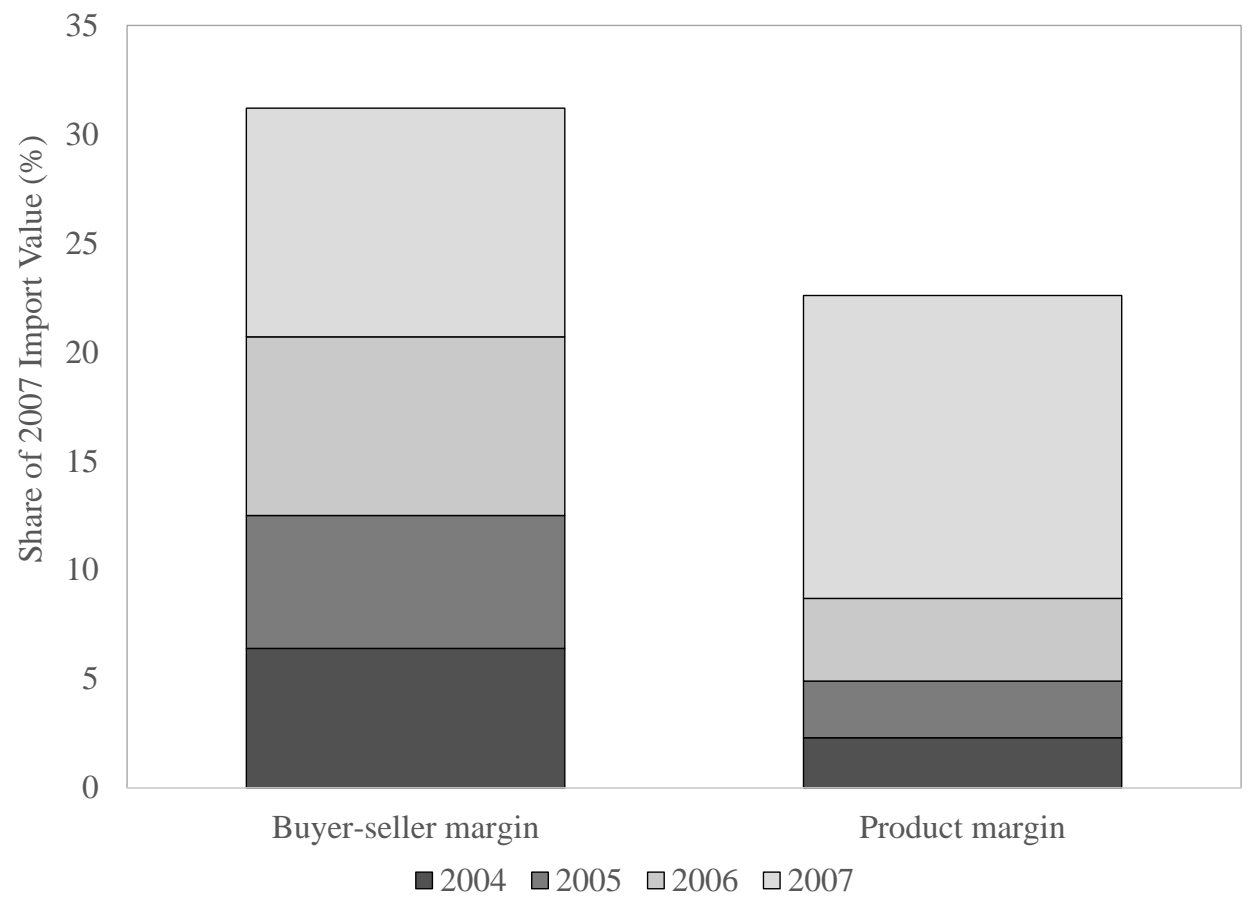

Note: The total of each bar is equal to the values for the buyer-seller and product extensive margins in Panel $\mathrm{B}$ of Table 4. This figure shows the contribution of the relationships formed (counting only products traded in that year of formation) in each year to 2007 import values as well as the contribution of new products added to existing relationships to the value of imports in 2007.

Finding 4: The formation of new buyer-seller matches and the introduction of new products into existing relationships are sensitive to movements in the exchange rate

It is possible that trade shocks, such as movements in the value of the exchange rate, will affect the formation of buyer-seller matches as well as the set of products traded within buyerseller relationships. An appreciation of the destination-market currency acts as a negative cost shock for the exporter, allowing the exporter the possibility of overcoming fixed costs associated with adding a marginal trade partner, and fixed costs associated with adding a marginal product within an existing buyer-seller relationship. This will result in a positive relationship between the exchange rate (defined exporter currency per destination-market currency) and the establishment of new buyer-seller matches, as well as the exchange rate and the addition of new products to existing relationships. 
Figure 6: Survival Probability of Buyer-Seller and Product Relationships Established in 2004

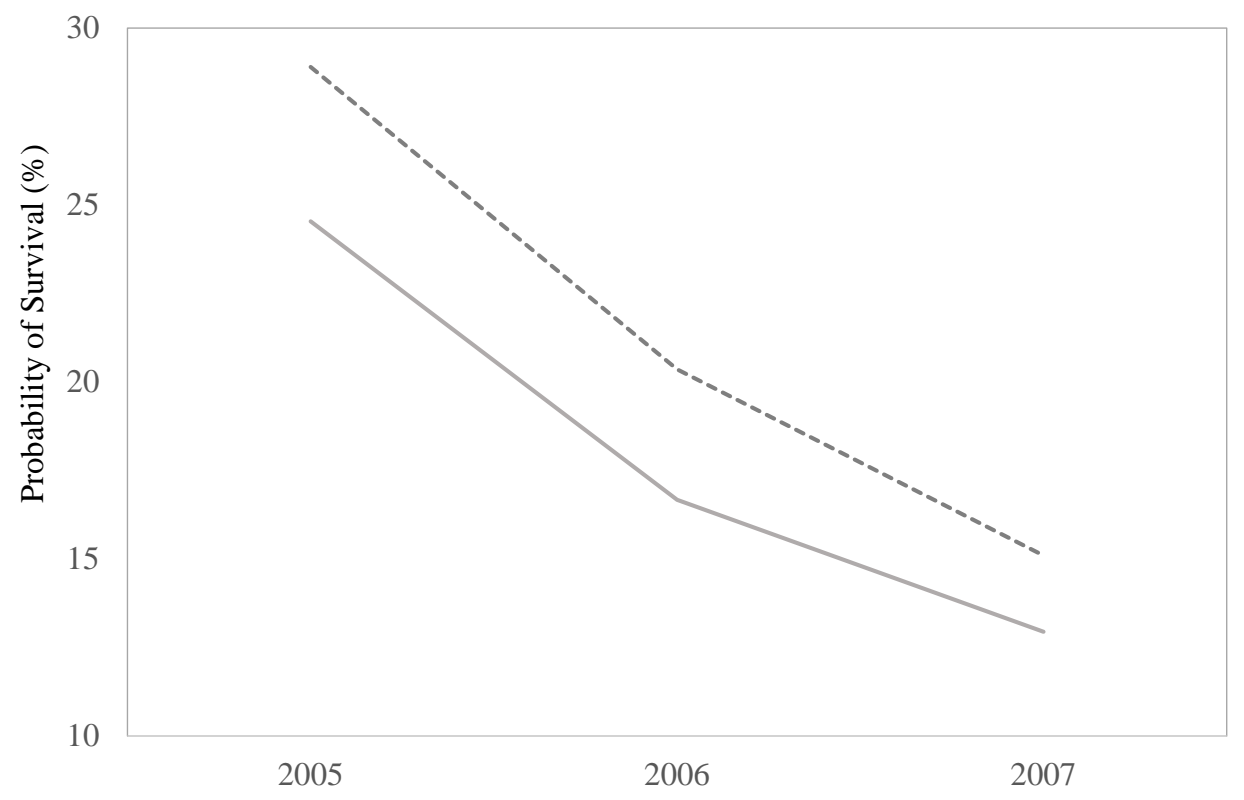

— New buyer-seller relationships --- New products into existing buyer-seller relationships

Note: This figure is constructed by first taking the total number of new relationships and new products added to existing relationship in 2004 and then dividing the surviving buyer-seller and product relationships in each subsequent year by the total number of new relationships and new products in 2004 .

Figure 7: Survival Probability of New Buyer-Seller and Product Relationships by Initial Size Quintile

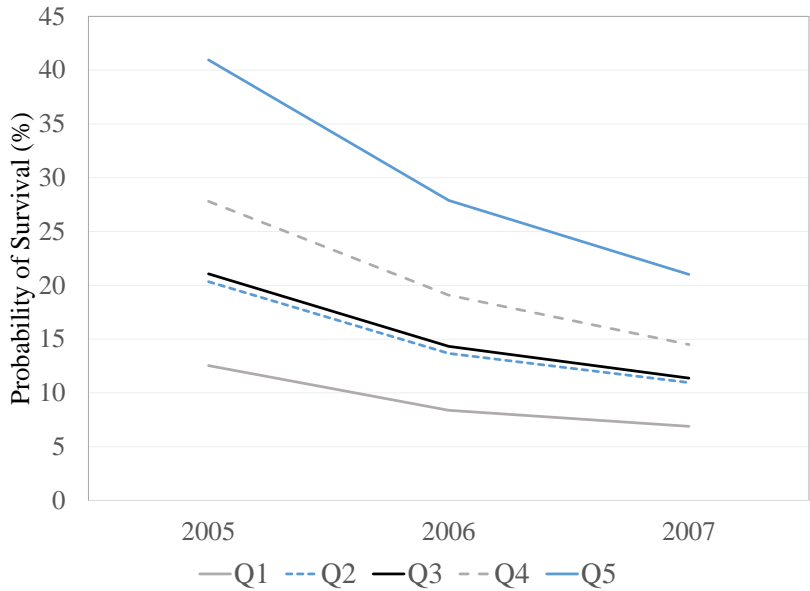

(a) Buyer-seller relationships

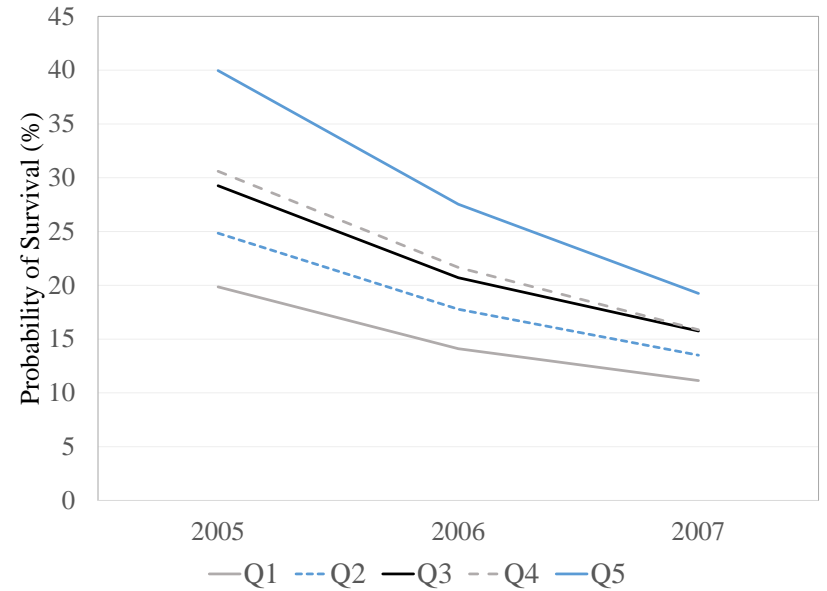

(b) New products into existing relationships

Note: Panel (a) presents the probability that a new buyer-seller relationship formed in 2004 survives into subsequent years by quintiles of the 2004 new relationship value distribution. Panel (b) presents the probability that a new product added to an existing relationship in 2004 is traded between the importer and exporter in subsequent years, by quintiles of the 2004 new product-relationship value distribution. 
To explore these relationships in the data, we start by running the following regression:

$$
\Delta y_{i t}=c+\beta \Delta e x_{t}+Z_{t}^{\prime} \gamma+\sigma t i m e+\alpha_{i}+\epsilon_{i t},
$$

where $\Delta y_{i t}$ can be the quarter-over-quarter change (log difference) at time $t$ in the number of importer $i$ trade partners, product or products per relationship. $\Delta e x_{t}$ is the quarterly log difference of the Canada-U.S. exchange rate (defined as USD per CAD), $Z_{t}$ is a control variable for aggregate demand shocks, time is a linear time trend, $\alpha_{i}$ is an importer-specific fixed effect, and $\epsilon_{i t}$ is an error term. Although importers may form relationships or adjust relationships (in terms products) in many different countries, we use the Canada-U.S. bilateral exchange rate as a proxy for the relevant exchange rate. Over the sample period, 86 percent of transactions and 88 percent of the value of Canadian imports are priced in U.S. dollars, making the Canada-U.S. bilateral exchange rate the most relevant exchange for short-run adjustments.

Table 5 presents the results of these regressions. Columns I and II show that an appreciation of the Canadian dollar is associated with an increase in the number of trade partners for importers. In column II, where we include Canadian GDP growth as a control for demand shocks, we see that a 1 percent appreciation is a associated with a 0.146 percent increase in the number of trade partners. Columns III and IV show a similar positive relationship between the exchange rate and the number of products per importer, with column IV showing that a 1 percent appreciation is associated with and 0.138 percent increase in the number of products for importers. Finally, columns V and VI show that an increase in the exchange is associated with an increase in the number of products per trade relationship for importers, with the estimated elasticity being 0.053 in column VI.

While these results are informative and suggest that firms adjust their set and constitution of relationships in response to exchange rate shocks, the dependent variables are not entirely analogous to the decomposition presented in Table 4 . To better approximate how these margins react to exchange rate shocks, we also run the following logit regressions:

$$
\operatorname{Pr}\left(Y_{i t}\right)=\frac{\exp \left(v_{i t}\right)}{1+\exp \left(v_{i t}\right)}
$$

where

$$
v_{i t}=c+\beta \Delta e x_{t}+Z_{t}^{\prime} \gamma+\sigma t i m e+\alpha_{i}+\epsilon_{i t} .
$$

Depending on the specification, $\operatorname{Pr}\left(Y_{i t}\right)$ refers to the probability of an importer $i$ in quarter $t$ adding a trade partner or a new product into one of its existing relationships. All other variables in the definition of $v_{i t}$ are the same as in (2.1).

Columns I and II in Table 6 report the results where $Y_{i t}$ is an indicator that firm $i$ added a 
Table 5: Regression Results for the Change in the Number of Partners and Products

\begin{tabular}{|c|c|c|c|c|c|c|}
\hline & \multicolumn{2}{|c|}{ Importer Partners } & \multicolumn{2}{|c|}{ Importer Products } & \multicolumn{2}{|c|}{ Relationship Products } \\
\hline & I & II & III & IV & $\mathrm{V}$ & VI \\
\hline Exchange rate $\left(\Delta e x_{t}\right)$ & $\begin{array}{c}0.153^{* * *} \\
(0.028)\end{array}$ & $\begin{array}{c}0.146^{* * *} \\
(0.028)\end{array}$ & $\begin{array}{c}0.150^{* * *} \\
(0.031)\end{array}$ & $\begin{array}{c}0.138^{* * *} \\
(0.032)\end{array}$ & $\begin{array}{c}0.060^{* * *} \\
(0.015)\end{array}$ & $\begin{array}{c}0.053^{* * *} \\
(0.015)\end{array}$ \\
\hline Canadian GDP growth & & $\begin{array}{c}0.695^{* *} \\
(0.286)\end{array}$ & & $\begin{array}{c}1.316^{* * *} \\
(0.321)\end{array}$ & & $\begin{array}{c}0.930^{* * *} \\
(0.153)\end{array}$ \\
\hline Time trend & $\begin{array}{c}-0.003^{* * *} \\
(0.000)\end{array}$ & $\begin{array}{c}-0.003^{* * *} \\
(0.000)\end{array}$ & $\begin{array}{c}-0.004^{* * *} \\
(0.000)\end{array}$ & $\begin{array}{c}-0.003^{* * *} \\
(0.000)\end{array}$ & $\begin{array}{c}-0.004^{* * *} \\
(0.000)\end{array}$ & $\begin{array}{c}-0.003^{* * *} \\
(0.000)\end{array}$ \\
\hline Constant & $\begin{array}{c}0.048^{* * *} \\
(0.003)\end{array}$ & $\begin{array}{c}0.039^{* * *} \\
(0.004)\end{array}$ & $\begin{array}{c}0.047^{* * *} \\
(0.003)\end{array}$ & $\begin{array}{c}0.031^{* * *} \\
(0.005)\end{array}$ & $\begin{array}{c}0.049^{* * *} \\
(0.002)\end{array}$ & $\begin{array}{c}0.038^{* * *} \\
(0.022)\end{array}$ \\
\hline Firm FE & Yes & Yes & Yes & Yes & Yes & Yes \\
\hline Quarter FE & Yes & Yes & Yes & Yes & Yes & Yes \\
\hline Obs. & 688,152 & 668,152 & 668,152 & 668,152 & $2,252,656$ & $2,252,656$ \\
\hline
\end{tabular}

Note: Results based on estimates of equation (2.1), where the dependent variable $\Delta y_{i t}$ is the quarter-over-quarter change in the number of trade partners per importer (columns I and II), the change in the number of products per importer (columns III and IV), or change in the number of products within importer-exporter relationships (columns $\mathrm{V}$ and $\mathrm{VI}$ ) at time $t$.

new trade partner in quarter $t 5^{5}$ In both columns (with and without a control demand shocks), the positive and statistically significant coefficient on the exchange rate suggests that an appreciation of the Canadian dollar increases the probability that importing firms add new trade partners. Columns III and IV report the results where $Y_{i t}$ is an indicator that firm $i$ added a new product to an existing trade relationship in quarter $t t^{6}$ Again, both columns report a positive and statistically significant coefficient on the exchange rate term, indicating that an appreciation of the Canadian dollar increases the probability that importers add new products to their existing relationships with foreign sellers.

\section{A Model of Multi-Product Exporters and Endogenous Matching}

In this section, we develop a partial equilibrium framework that models the market for imports as characterized by the interaction of exporters/sellers and importers/buyers.7 This allows us to represent the data features described above in the form of a theoretical model, with

\footnotetext{
${ }^{5} \mathrm{~A}$ new relationship is flagged in the same way it was done for Table 4 , Panel A. That is, the new relationship did not exist at any point over the previous four quarters.

${ }^{6} \mathrm{~A}$ new product added to an existing relationship is flagged in the same way it was done for Table 4 Panel A. That is, the product was not traded at any point over the previous four quarters, but the buyer-seller relationship did exist.

${ }^{7}$ The model is similar to Bernard et al. (2018). It is a partial equilibrium framework. But more importantly, we model both a relation-specific fixed cost and a product-specific fixed cost to capture the extensive margins on both fronts.
} 
Table 6: Adding a New Trade Partner or New Product into an Existing Relationship (logit)

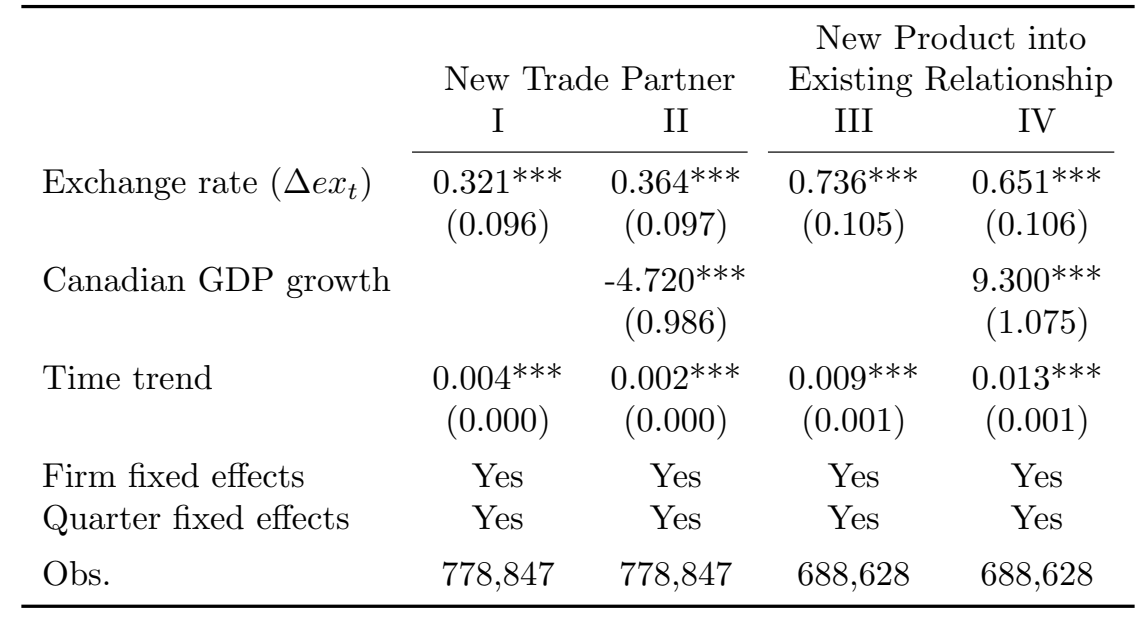

Note: Results based on estimates of equation (2.2), where the dependent variable $\operatorname{Pr}\left(Y_{i t}\right)$ is the probability that an importing firm $i$ adds a new trade partner (columns I and II) or the probability that an importing firm adds a new product to an existing relationship with an exporter (columns III and IV).

some the key features of the model being that importers and exporters are heterogeneous in terms of the productivity, exporters can produce and sell multiple products and there is endogenous matching between importers and exporters. The model is then used to delve deeper into the mechanisms at play when there is an exchange rate shock, which is explored in the next section.

In the model, there is an imported final good produced with intermediate inputs imported by a measure $B$ of buyer firms who are purchasing the goods from a measure $S$ of sellers. Both buyers and sellers are arranged in inverse order of productivity, so that buyer $b$ is more productive (as described fully below) than $b^{\prime}$ if $b<b^{\prime}$, and similarly seller $s$ is more productive that $s^{\prime}$ if $s<s^{\prime}$. The total number of active buyer firms is denoted $\tilde{B} \leq B$ and the total number of active sellers is $\tilde{S} \leq S$. An active buyer is one that has an endogenously determined relationship with at least one seller. Each active buyer imports an endogenous range of intermediate inputs from each seller it interacts with, which it then combines into a composite good, and then combines all composite goods into a unique final good that is sold to domestic consumers. The buyer firms are monopolistic competitors and set a price markup over their marginal cost. Sellers choose the measure of buyers to whom they offer their intermediate goods and, in addition, choose the measure of product varieties to offer to each of these buyers. Finally, for each variety sold to a given buyer, sellers set their price as a markup over marginal cost. Note that the sellers could be located in different countries, but for now we do not allow for this to simplify notation. 


\subsection{Utility and production}

The domestic consumer in the importing country has preferences over final import goods given by

$$
C=\left(\int_{0}^{\tilde{B}} C(b)^{\left(1-\frac{1}{\rho}\right)} d b\right)^{\frac{1}{1-\frac{1}{\rho}}}
$$

where $C(b)$ is the purchase of the brand of the final good produced by buyer $b$. We also assume that there is an outside good consumed by the domestic consumer. We take the price of this outside good as given, and assume that that the demand for the final imported good, relative to the outside good can be written as

$$
C=P^{-\gamma} Y
$$

where $P$ is the price index for the final imported good, $\gamma$ is the substitution elasticity between the final import good and the outside good and $Y$ is total domestic demand.

The buyer firm $b$ produces using a range $S_{b}$ of intermediate goods according to the production technology

$$
C(b)=\left(Z(b) \int_{0}^{\tilde{S}(b)} x(b, s)^{\left(1-\frac{1}{\eta}\right)} d s\right)^{\frac{1}{1-\frac{1}{\eta}}} .
$$

Here, $Z(b)$ is the exogenous productivity of the buyer firm, and $x(b, s)$ represents the composite basket that is purchased by buyer $b$ from seller $s$. As noted above, we assume that $Z(b)$ is ordered so that $Z(b) \geq Z\left(b^{\prime}\right)$ when $b<b^{\prime}$.

The composite goods basket offered by each seller is in turn produced by combining individual varieties $x(b, s, g)$ according to the aggregator

$$
x(b, s)=\left(\int_{0}^{G(b, s)} x(b, s, g)^{\left(1-\frac{1}{\sigma}\right)} d g\right)^{\frac{1}{1-\frac{1}{\sigma}}}
$$

where $G(b, s)$ represents the measure of varieties of the seller $s$ offered to buyer $b$.

The seller produces each variety $g$ for buyer firm $b$ according to the linear technology

$$
x(b, s, g)=\frac{z(s)}{\tau(s) h(s, g)} \ell(s, g)
$$

where $\tau(s)$ is a conventional trade (iceberg) cost, and $\frac{z(s)}{h(s, g)}$ is the productivity of firm $s$ in producing variety $g$, where we assume that $h_{g}(s, g)>0$, so that the firm becomes less productive as it departs from its "core competence." 8 as labour), which has a fixed price $w(s)$.

\footnotetext{
${ }^{8}$ We model core competency similar to Eckel and Neary (2010) and Arkolakis, Ganapati and Muendler (2019).
} 
Importantly, the selling firm incurs two types of fixed costs. There is a fixed cost $f(b, s)$ of selling to buyer $b$, and there is a fixed cost of each additional variety it offers to each buyer, given by $f(b, s, g)$. These fixed costs will play an important role in the determination of buyerseller relationships because the profits associated with the combined productivities of the buyer and seller will have to be high enough to overcome these fixed costs in order to establish a relationship.

\subsection{Final demand and importer price setting}

Domestic demand for the importer b's final product (or brand) is determined by

$$
C(b)=\left(\frac{p(b)}{P}\right)^{-\rho} C,
$$

where $p(b)$ is the price set by the importer for their product and

$$
P=\left(\int_{0}^{\tilde{B}} p(b)^{(1-\rho)} d b\right)^{\frac{1}{1-\rho}}
$$

is the price index for the final imported good.

Given this, profit maximization by active an buyer $b$ is as follows. Profits are defined as

$$
\Pi(b)=(p(b)-q(b)) C(b)
$$

where

$$
q(b)=\left(Z(b)^{\eta} \int_{0}^{S(b)} q(b, s)^{1-\eta} d s\right)^{\frac{1}{1-\eta}}
$$

is the unit cost for the buyer, $q(b, s)$ is cost of an individual composite good purchased from seller $s$, and $S(b)$ is the total measure of sellers that sell to buyer $b$. In turn, we can define the cost of the composite good $q(b, s)$ as an aggregate over the prices of the individual varieties $g$ produced by seller $s$ for sale to buyer $b, q(b, s, g)$. That is,

$$
q(b, s)=\left(\int_{0}^{G(b, s)} q(b, s, g)^{1-\sigma} d g\right)^{\frac{1}{1-\sigma}}
$$

The optimal retail price for buyer $b$ is a markup over the marginal cost of the composite good

$$
p(b)=\hat{\rho} q(b)
$$


where $\hat{\rho} \equiv \frac{\rho}{\rho-1} l^{9}$ When all buyers use the same markup rule, the total sales for buyer $b$ are

$$
\left(\frac{\hat{\rho} q(b)}{P}\right)^{-\rho} P^{-\gamma} Y=q(b)^{-\rho}\left(\int_{0}^{\tilde{B}} q(b)^{(1-\rho)} d b\right)^{\frac{\rho-\gamma}{1-\rho}} \hat{\rho}^{-\gamma} Y
$$

and total revenue is

$$
\hat{\rho}^{1-\gamma} q(b)^{1-\rho}\left(\frac{\hat{\rho} q(b)}{P}\right)^{-\rho} P^{-\gamma} Y=\hat{\rho}^{1-\gamma} q(b)^{1-\rho}\left(\int_{0}^{B} q\left(b^{\prime}\right)^{(1-\rho)} d b^{\prime}\right)^{\frac{\rho-\gamma}{1-\rho}} Y .
$$

\subsection{The seller's problem}

Each exporter $s$ has three things to choose. First, it must choose a price $q(b, s, g)$ for each product variety $g$ that it is offering to buyer $b$. Secondly, for each buyer, it will choose the measure of varieties to sell $G(b, s)$. Finally, it has to choose the measure (or number) of buyers to trade with. For the latter two choices, we use a cut-off rule, assuming that there is a maximum measure of varieties $G(b, s)$ for each buyer $b$ that the seller can profitably supply and there is a maximum measure of buyers $B(s) \leq B$ that the seller can supply to and make a profit. In each case, these must be functions of the buyer's productivity, the seller's productivity, and trade costs. But before we make this relationship explicit, we can start by stating the optimality conditions for the seller.

Buyer b's demand for seller $s$ 's product variety $g$ is

$$
x(b, s, g)=\left(\frac{q(b, s, g)}{q(b, s)}\right)^{-\sigma} x(b, s),
$$

where $x(b, s)$ is $s$ 's demand for the total product line of seller $s$

$$
x(b, s)=\frac{Z(b)^{\eta} q(b, s)^{-\eta}}{q(b)^{-\eta}} C(b) .
$$

Finally, overall demand for buyer b's product line is (as defined above)

$$
Y(b)=q(b)^{-\rho}\left(\int_{0}^{\tilde{B}} q\left(b^{\prime}\right)^{(1-\rho)} d b^{\prime}\right)^{\frac{\rho-\gamma}{1-\rho}} \hat{\rho}^{-\gamma} Y .
$$

\footnotetext{
${ }^{9}$ We assume that in setting retail prices, buyers behave as monopolistic competitors. This differs from the assumptions we make about sellers. Allowing buyers to price strategically would complicate the analysis without changing the predictions of the model. Since we do not have data on retail prices, we cannot assess to whether an assumption of variable retail markups are supported empirically. A number of papers provide support for variable exporter markups, including with the data set used in this papers (see Devereux, Dong and Tomlin, 2017).
} 
Sellers are multi-product monopolistic competitors. They choose the range of prices for their own goods, taking into account an elasticity $\sigma$ for each variety of the good and an elasticity $\eta$ for their own product line relative to other sellers. Since $Z\left(b^{\prime}\right) \leq Z(b)$ for $b^{\prime} \geq b$, in choosing buying firms to trade with, the seller will first sell to firms with higher productivity.

We can then describe the sellers profit maximization problem as the joint maximization associated with the three decisions described above. That is, they must choose (i) the price, $q(b, s, g)$, of their varieties, (ii) the range of varieties $G(b, s)$ to sell within each relationship, and (iii) the total number of relationships $B(s)$, to maximize profits, defined as

$$
\int_{0}^{B(s)} \int_{0}^{G(b, s)}\left(q(b, s, g)-\frac{\tau(s) h(s, g) w(s)}{z(s)}\right) x(b, s, g) d g d b-\int_{0}^{B(s)} \int_{0}^{G(b, s)} f(b, s, g) d g d b-\int_{0}^{B(s)} f(b, s) d b
$$

where $f(b, s, g)$ is the fixed cost of adding variety $g$ to the relationship between $b$ and $s$, and $f(b, s)$ is the fixed cost of establishing a relationship between $b$ and $s$

(i) Optimal pricing: The optimal price for the seller is

$$
q(b, s, g)=\mu(b, s) \frac{\tau(s) w(s) h(s, g)}{z(s)} .
$$

The seller is a multi-product firm and uses the "outer" price elasticity to determine the markup, $\mu(b, s)$, over marginal cost. In light of the extreme granularity of the import market, as documented in Finding 1 in the previous section, we allow for sellers to internalize the impact that their pricing decisions have on the market price. Therefore, in choosing $q(b, s)$, seller $s$ will take account of its affect on $q(b)=\left(Z(b)^{\eta} \int_{0}^{S(b)} q(b, s)^{1-\eta} d s\right)^{\frac{1}{1-\eta}}$. The optimal markup for firm $s$ is then

$$
\mu(b, s)=\frac{\eta+(\rho-\eta)\left(\frac{q(b, s)}{q(b)}\right)^{1-\eta}}{\eta+(\rho-\eta)\left(\frac{q(b, s)}{q(b)}\right)^{1-\eta}-1} .
$$

The expression $\left(\frac{q(b, s)}{q(b)}\right)^{1-\eta}$ is a measure of the market share of seller $s$ in all sales to buyer $b$. A reasonable assumption is that the "within" buyer elasticity of substitution $\eta$ exceeds the "across" buyers' elasticity of substitution $\rho$. This implies the familiar result that the seller markup is declining in market share. As shown in Devereux, Dong and Tomlin (2017), this leads to the implication that exchange rate pass-through is lower for firms with a larger market share 10

\footnotetext{
${ }^{10}$ Other papers that show the negative relationships between exchange rate pass-through and exporter size include Berman, Martin and Mayer (2012) and Amiti, Itskhoki and Konings (2014) who show that exchange rate pass-through decreases monotonically in exporter market share. Feenstra, Gagnon and Knetter (1996), Garetto (2016) and Auer and Schoenle (2016) emphasize a U-shaped relationship between exporter market share and pass-through.
} 
(ii) Range of varieties: For each $b$, the seller determines the extent of product variety to offer. This is represented by the condition that at $G(b, s)$ the seller makes zero net profit, given the fixed cost already paid for selling to $b$. Thus, the cut-off condition is

$$
\left(q(b, s, G(b, s))-\frac{\tau(s) w(s) h(b, s, G(b, s))}{z(s)}\right) x(b, s, G(b, s))-f(b, s, G(b, s))=0 .
$$

Note that there is one of these conditions for each buyer.

(iii) Determination of the measure of buyers: The number of buyers that an exporter sells to is determined by the condition that at the marginal buyer, denoted $B(s)$, the exporter makes zero net profit. That is, at $B(s)$, we have

$$
\int_{0}^{G(B(s), s)}\left(q(B(s), s, g)-\frac{\tau(s) w(s) h(B(s), s, g)}{z(s)}\right) x(B(s), s, g) d g-\int_{0}^{G(B(s), s)} f(B(s), s, g) d g-f(B(s))=0 .
$$

Writing out the full expression for $x(b, s, g)$

$$
x(b, s, g)=\left(\frac{q(b, s, g)}{q(b, s)}\right)^{-\sigma} \frac{Z^{\eta} q(b, s)^{-\eta}}{q(b)^{-\eta}} \frac{q(b)^{-\rho}}{\left(\int_{0}^{B} q\left(b^{\prime}\right)^{(1-\rho)} d b^{\prime}\right)^{\frac{\gamma-\rho}{1-\rho}}} Y .
$$

Substituting into the two conditions for optimal $b$ and $G$, using the markup condition gives us

$$
\begin{gathered}
\frac{\mu(b, s)^{-\sigma}}{\mu(b, s)-1}\left(\frac{\tau(s) w(s) h(b, s, G(b, s))}{z(s)}\right)^{1-\sigma} q(b, s)^{\sigma-\eta} Z(b)^{\eta} q(b)^{\eta-\rho}\left(\int_{0}^{\tilde{B}} q\left(b^{\prime}\right)^{(1-\rho)} d b^{\prime}\right)^{\frac{\rho-\gamma}{1-\rho}} \hat{\rho}^{-\gamma} Y \\
-f(b, s, G(b, s))=0
\end{gathered}
$$

and

$$
\begin{gathered}
\int_{0}^{G(B(s), s)}\left[\frac{\mu(B(s), s)^{-\sigma}}{\mu(B(s), s)-1}\left(\frac{\tau(s) w(s) h(B(s), s, g)}{z(s)}\right)^{1-\sigma} q(B(s), s)^{\sigma-\eta} Z^{\eta} q(B(s))^{\eta-\rho}\right. \\
\left.\quad \times\left(\int_{0}^{\tilde{B}} q\left(b^{\prime}\right)^{(1-\rho)} d b^{\prime}\right)^{\frac{\rho-\gamma}{1-\rho}} \hat{\rho}^{-\gamma} Y\right] d g \\
-\int_{0}^{G(B(s), s, g)} f(B(s), s, g) d g-f(B(s))=0 .
\end{gathered}
$$

\subsection{Calibration and model characteristics}

In this subsection, we begin to explore the characteristics of the model and how well it can explain the findings detailed in section 2. In order to to this, we need to calibrate the model parameters and numerically solve for the static equilibrium, and we start by transforming the 
continuous measures of buyers, sellers and goods into discrete measures. We assume there is a maximum of 100 buyers, 100 sellers and 8 separate goods that each seller can offer to any buyer. It will depend on the exact calibration, but in most circumstances, not all matches between buyers and sellers will be achieved because the lowest productivity buyers and sellers will seldom trade with each other, and the goods farthest from a seller's core competency will seldom be produced.

For an initial calibration of the model's parameters, we turn to the existing literature. Using U.S. data, Feenstra et al. (2018) estimate the microelasticity across individual industries (the substitution elasticity between alternative foreign import sources) to be around 3 to 4 depending on the empirical method used - and the macroelasticities (the substitution elasticity between domestic and foreign import sources) to be lower. We follow their findings, setting $\eta$ and $\rho$ at 3.5 and 3.25 respectively, and set $\gamma$ somewhat smaller, at 3 .

The productivity of sellers and buyers follows a Pareto distribution in the form of $F(z)=$ $k z^{-(k+1)}$, where $k$ is the shape parameter 11 Calibrated to the U.S. data, Melitz and Redding (2015) set the Pareto shape parameter for firm productivity to be 4.25, and Bernard, Redding and Schott (2009) set it equal to 4. Estimating using French firm level data, Nigai (2017) found that a Pareto shape parameter would take a value of 1.9. Lower values of $k$ correspond to greater firm heterogeneity. We set $k=3$ in our simulation.

We assume that additional products farther away from a seller's core competency incur higher unit costs. To model this, we assume that $h(g)=(1+h)^{g}$, where $h=0.03$. The existing literature does not provide much guidance on the shape of $h(g)$; however, the value of $h$ has been chosen to be roughly in line with the marginal-cost schedule estimated in Arkolakis, Ganapati and Muendler (2019). Finally, we calibrate fixed costs so that, at the initial state, all buyers and all sellers are active, but the least productive buyer deals only with the sellers in the 90th and above percentile distribution of productivity, and the least productive seller sells only to buyers in the 90th percentile and above in distribution of buyer productivity. It is important to note that this essentially shuts down the importer extensive margin in the analysis that follows. As shown in Table 4, this margin makes a relatively small contribution to import flows, so we shut the margin down in the model to simplify the analysis.

With this calibration, we can now solve for the static equilibrium and examine how the static distributions compare to Findings 1 and 2 from the previous section. Figures 8 (a) and (b) represent the equilibrium of the model in the baseline steady state in a form that is analogous to Figures 1(a) and (b) - that is, the distribution of total import value as a function of the

\footnotetext{
${ }^{11}$ The Pareto distribution has been the common choice for approximating the shape of firm productivity distribution, though the Pareto assumption is sometimes challenged when Log-normal provides a closer fit to the left tail of distribution. See also Fernandes et al. (2018).
} 
Figure 8: Importer and Exporter Share of the Import Market by Percentile Bin (model)

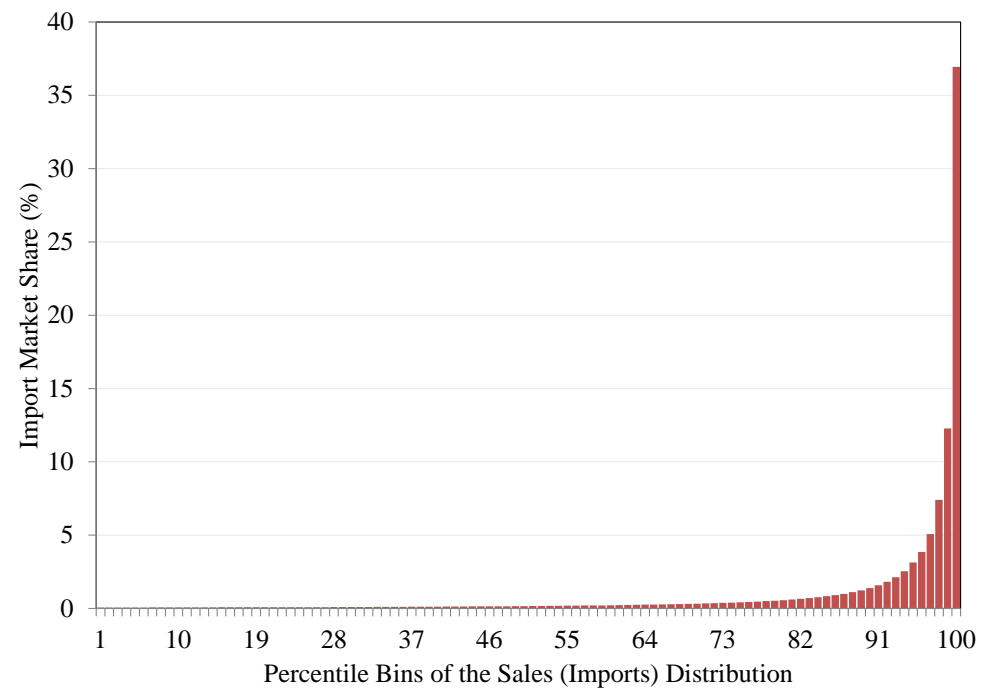

(a) Importers

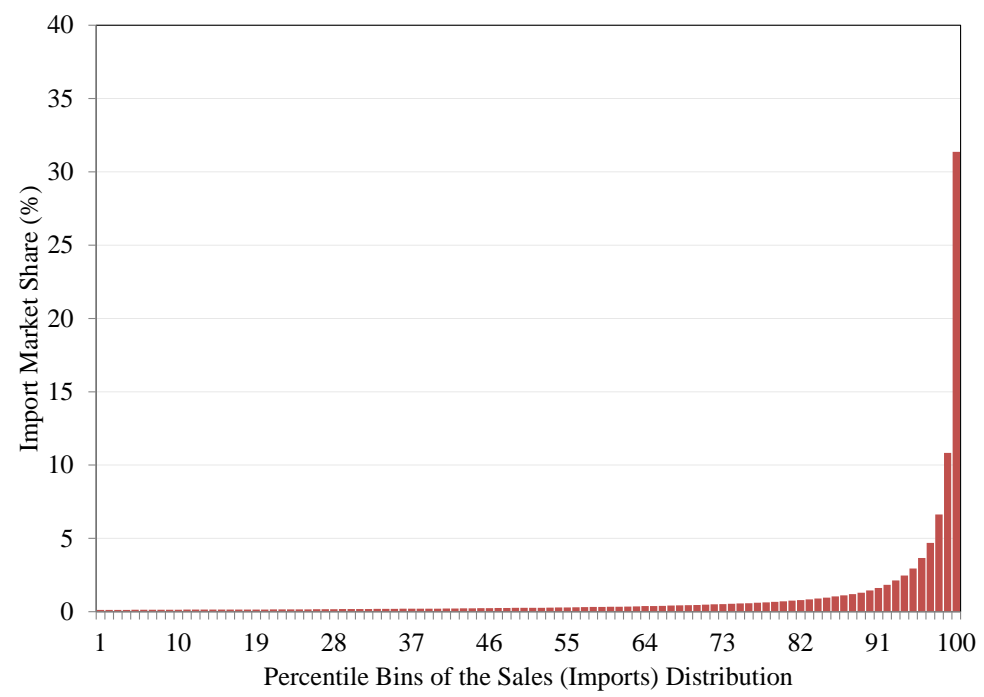

(b) Exporters

Note: Panel (a) presents the model results for the share of import value accounted for by importing firms in each percentile of the import-value distribution. Panel (b) presents the share of Canadian imports accounted for by exporting firms in each percentile of the import-value distribution.

percentile size of importers and exporters, respectively. In both cases, we see that the share of total imports is sharply skewed towards large buyer and seller firms. Our chosen Pareto shape parameter leads to the top one percent of importer and exporter firms accounting for around 35 percent of the total value of imports. This represents a lower degree of concentration than we see in the data, but nevertheless constitutes a high degree of concentration.

Figure 9(a) illustrates the distribution of exporters per importer and importers per exporter 
as a function of the percentile distribution of import value. As in the data, we see that the distribution is skewed to the right - the smallest importing firms have only a few export suppliers, while the largest receive exports from all firms. A similar pattern is seen for the distribution of importers along the distribution of exporting firms. Figure 9(b) shows that larger importers purchase more goods from each exporter, and larger exporters sell more goods to each importer, as we see in the data (see Table 2 and Figures 2-4). The largest buyers import all 8 goods from all exporters, while the largest exports sell all 8 goods to all importers. Therefore, the basic granular characteristics of the data are features of the model.

\subsection{Dynamic distributions: model simulation to explore margins}

To explore how the contribution of the different margins of trade work within the model, we simulate the model's response to aggregate shocks. More specifically, we hit the model with a continuous series of aggregate shocks and calculate the share of the different margins in each

of the model's one-period-ahead responses. We then average across all periods to calculate the shares of the buyer-seller and product extensive margins as well as the pure intensive margin, which we then compare to the short-run margin contributions observed in the data.

The aggregate shocks we focus on are demand and seller cost shocks - that is, shocks to $Y$ and $w$ in the model, respectively. We assume that they both follow an $\operatorname{AR}(1)$ process with a persistence parameters equal to 0.9 and evolve based on continuous i.i.d. shocks:

$$
Y^{\prime}=0.9 Y+\epsilon^{\prime} \text { where } \epsilon^{\prime} \sim N\left(0, \sigma_{\epsilon}^{2}\right)
$$

and

$$
w^{\prime}=0.9 w+\zeta^{\prime} \text { where } \zeta^{\prime} \sim\left(0, \sigma_{\zeta}^{2}\right) .
$$

For each new set of draws of $\epsilon^{\prime}$ and $\zeta^{\prime}$, we re-calculate the static equilibrium and then determine the share of each margin in the transition from the previous equilibrium to the new one. We simulate the model in this way for 350 periods and then take the mean contributions of the margins over all the simulations. Because these are one-period adjustments, we equate them to the short-run adjustments of the previous section.

Table 7 presents the results of these calculations and shows that the model with the baseline calibration matches the data (Finding 3) quite well in several ways. In the model simulations, as in the data, we see that the share of transactions for the buyer-seller and product extensive margins is significantly higher than their value shares. This reflects the fact that adjustments along these margins come from either lower productivity (and hence low market share) importers and exporters adding or dropping trade partners and/or products, and larger importers and exporters adding marginal trade partners and products. That is, there are a significant number of these relationships being created or destroyed in response to the aggregate shocks, but they 
Figure 9: Number of Partners and Goods by Share of the Import Market by Percentile Bin (model)

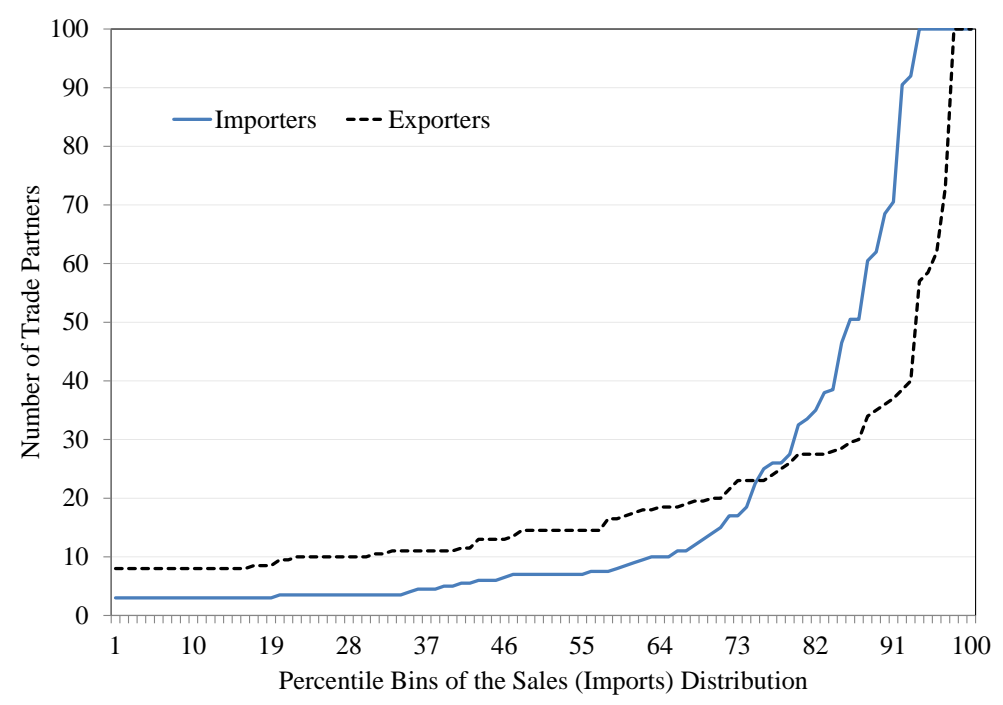

(a) Number of Trade Partners

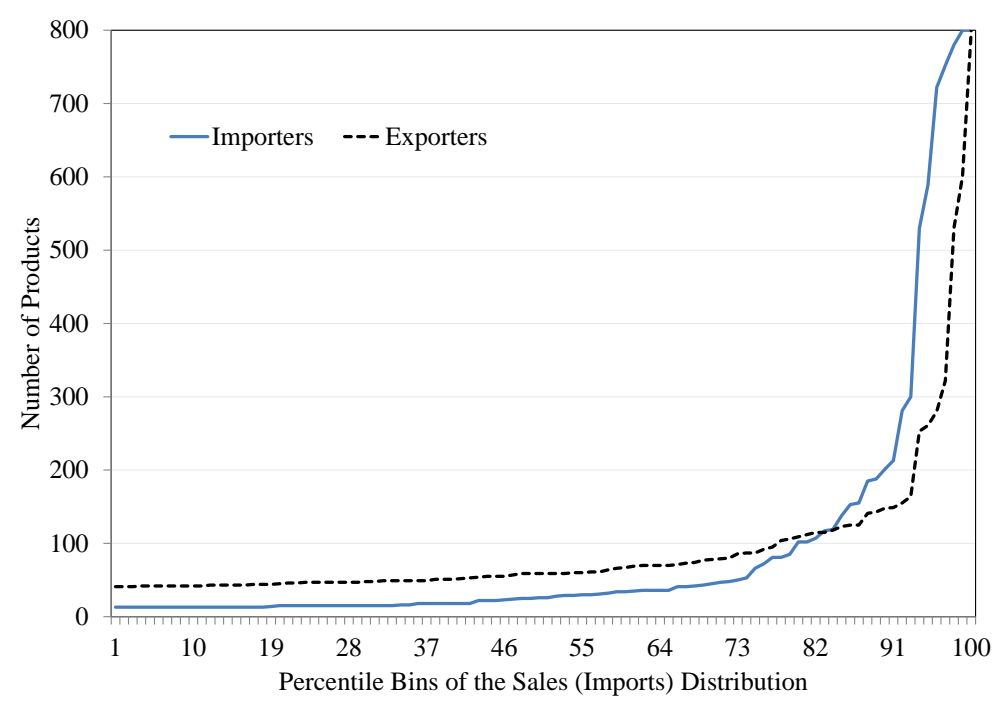

(b) Number of Goods

Note: Panel (a) presents the share of import value accounted for by importing firms in each percentile of the import-value distribution in the model simulations. Panel (b) presents the share of Canadian imports accounted for by exporting firms in each percentile of the import-value distribution in the model simulations.

are of relatively low value in the short run.

In both the model and the data, the average adjustment in total value is dominated by the pure intensive margin (roughly 88 percent in the data and 85 percent in the model). This is continuous buyer-seller-product relationships adjusting the value of the relationships by increasing or decreasing the number of units being exchanged as prices adjust with the demand and cost shocks. 
Table 7: Model Simulation Results and Fit

\begin{tabular}{lccccc}
\hline & \multicolumn{2}{c}{$\begin{array}{c}\text { Share of } \\
\text { Transactions }\end{array}$} & \multicolumn{2}{c}{ Share of Value } \\
& \begin{tabular}{c} 
Data \\
\cline { 5 - 6 } Buyer-seller extensive
\end{tabular} & Model & & Data & Model \\
\cline { 2 - 3 } \cline { 5 - 6 } Product extensive & 24.6 & 14.0 & & 8.1 & 3.6 \\
Pure intensive & 56.9 & 25.0 & & 3.4 & 11.4 \\
\hline
\end{tabular}

Note: The model margin contributions are based on simulating the response of the model to shocks to demand $(Y)$ and seller costs $(w)$ over 350 periods, and the average contributions to the model's adjustment to the shocks are reported in this table.

\section{Adjustment to an Exchange Rate Shock}

In this section we turn our attention to the specific effects of an exchange rate shock on the formation of new buyer-seller relationships and the addition of new products into existing relationships ${ }^{12}$ The model is static, so we do not directly calculate any long-run effects of exchange rates. Nevertheless, we do consider the long-run effects through indirect analysis of the short-run response in the margins of interest to movements in exchange rates. That is, if exchange rates affect the formation of new relationships, and there is reason to believe these relationships will survive, then they can have an effect on long-run outcomes.

To explore the response of the model to exchange rates, we assume that exchange rate shocks are equivalent to the cost shock in the model above in a two-country setup, so $w(s)=w$ for all $s \in S$. To get an initial feel for the role of exchange rates in the model, we first isolate the effects of the cost/exchange-rate shock in the simulations in the previous section. To do so, we take the simulation results and regress the change in the number of firm-to-firm matches and change in the number of products traded within existing relationships on the changes in the exchange rate and aggregate demand. Table 8 presents the results, which are the model counterparts to the results presented in columns II and VI in Table 5. The table shows that an exchange rate appreciation is associated with a highly significant increase in the number of firm-to-firm matches and in the number of products traded within relationships.

To go into more detail about the effects of exchange rate shocks on the different margins within the model, we replicate the simulation of the previous section but double the variance of the cost-shock draw, $\sigma_{\zeta}^{2}$. The difference between the baseline simulation and this current simulation, presented in Table 9, will further develop our understanding of the model's response to exchange rate shocks. The increase in the exchange rate shock has little effect on the value

\footnotetext{
${ }^{12}$ This section remains a work in progress.
} 
Table 8: Regressions Results Based on Model Simulation

\begin{tabular}{lcc}
\hline & $\begin{array}{c}\text { Change in Buyer-Seller } \\
\text { Relationships }\end{array}$ & $\begin{array}{c}\text { New Goods into } \\
\text { Existing Relationships }\end{array}$ \\
\cline { 2 - 3 } Exchange rate $(w)$ & $0.738^{* * *}$ & $0.102^{* * *}$ \\
& $(0.059)$ & $(0.008)$ \\
Demand shock $(Y)$ & $0.619^{* * *}$ & $0.087^{* * *}$ \\
& $(0.200)$ & $(0.029)$ \\
Constant & $0.001^{*}$ & 0.000 \\
Obs. & $(0.016)$ & $(0.012)$ \\
\hline
\end{tabular}

shares (compared with the baseline model - see column I versus column II) because imports are still dominated by the pure intensive margin. This is because any new relationships and/or products added to existing relationships are marginal and therefore have a low value relative to the core continuous relationships and products that make up the pure intensive margin.

Where the model does highlight the effects of larger exchange rate shocks is in the share of transactions. In columns III and IV, we see that an increase in the exchange rate shock has a large effect on the transaction shares, as the buyer-seller and product extensive margins shares increase from a total of 39 percent to a total of 56 percent. Therefore, it is clear that within the model that exchange rate shocks have a significant effect on the formation of buyer-seller relationships and on the set of goods traded within relationships.

Table 9: Model Simulations with Increased Exchange Rate Volatility

\begin{tabular}{lccccc}
\hline & \multicolumn{2}{c}{ Value Shares } & & \multicolumn{2}{c}{ Transaction Shares } \\
& $\begin{array}{c}\text { I } \\
\text { Baseline } \\
\text { Model }\end{array}$ & $\begin{array}{c}\text { More Volatile } \\
\text { Exchange Rate }\end{array}$ & $\begin{array}{c}\text { III } \\
\text { Baseline } \\
\text { Model }\end{array}$ & $\begin{array}{c}\text { IV } \\
\text { More Volatile } \\
\text { Exchange Rate }\end{array}$ \\
\cline { 2 - 3 } \cline { 5 - 6 } Buyer-seller extensive & 3.6 & 4.0 & & 14.0 & 24.0 \\
Product extensive & 11.4 & 7.0 & & 25.0 & 32.0 \\
Pure intensive & 85.0 & 89.0 & & 62.0 & 44.0 \\
\hline
\end{tabular}

Finally, in Figure 10, we illustrate the response to a 10 percent exchange rate appreciation (a one-time shock to the $\mathrm{AR}(1)$ process) of the destination-market currency along the different margins, repeatedly solving for the model equilibrium at the different values of the exchange rate as the shock dissipates. Panel (a) reports the response of total imports as well as the value response along the buyer-seller and product extensive margins. As seen previously, the greatest part of the adjustment takes place along the intensive margin. Panel (b) reports the absolute number of importer-exporter-product matches and importer-exporter pairings following an exchange rate depreciation. The number of relationships increases along both dimensions 
Figure 10: Model Response to an Exchange Rate Appreciation

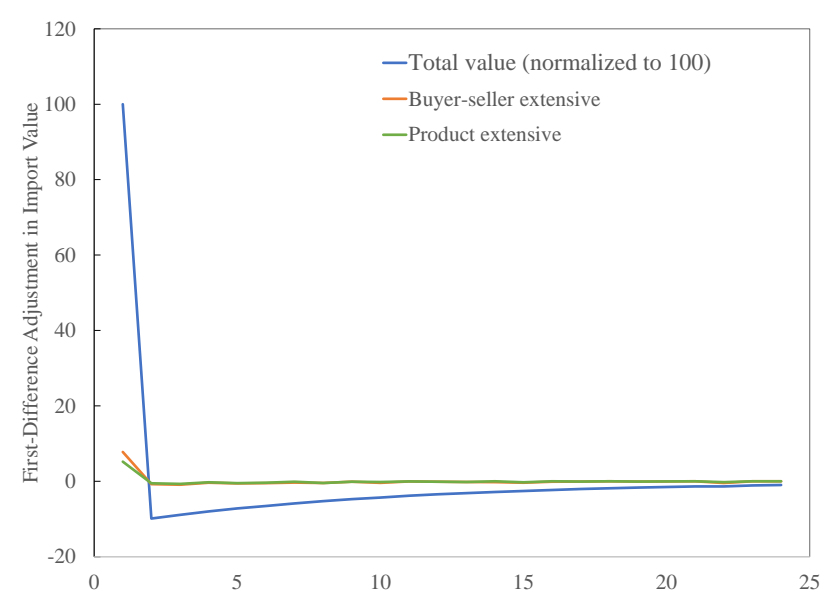

(a) Import value

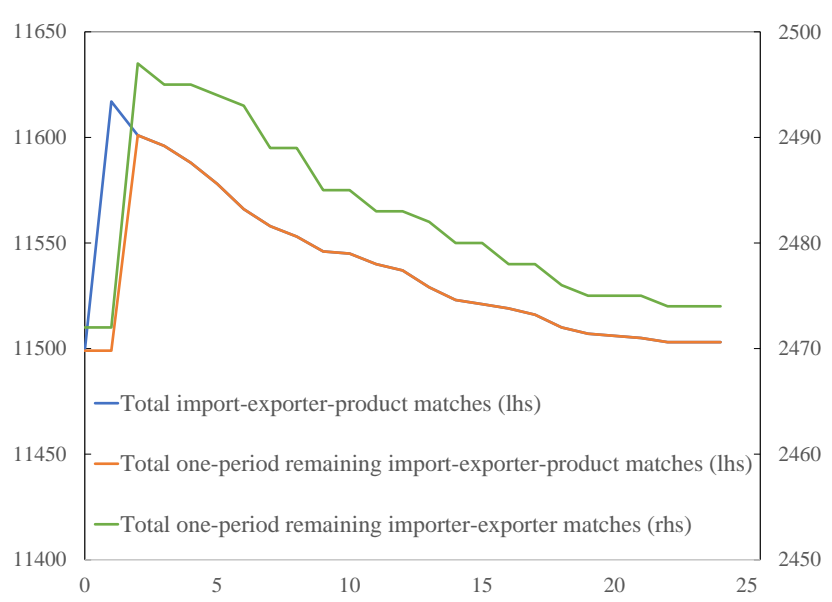

(b) Number of matches

immediately after the after the exchange rate shock and then slowly decreases as the shock dissipates.

Although the model is static, it can still shed light on the long-run effects of exchange rate shocks. The existence of fixed costs associated with the establishment of new relationships and the addition of new products suggest that some new relationships (firm-to-firm and new products) that formed as a result of an exchange rate appreciation may persist even when the exchange rate returns to its previous level. The magnitude of this effect is difficult to assess with a static model, but the results from the data (Tables 5 and 6 ) and in the model (Tables 8 and 9 and Figure 10 do suggest that these margins are highly sensitive to movements in the exchange rate.

\section{Conclusions}

This paper remains a work in progress. However, the initial data findings show that the formation of new trading relationships and adjustments within existing relationships - in terms of the products traded - are important contributors to long-run import flows in Canada. Moreover, we show that the buyer-seller extensive and product extensive margins are sensitive to movements in the exchange rate. We build a model of international trade with monopolistic competition, endogenous buyer-seller matching and multi-product exporters that can replicate many of the findings relating to distributions across buyer-seller-product relationships.

The model also features fixed costs associated with the establishment of new trade relationships and the addition of products to existing relationships. These fixed costs imply a degree of persistence when it comes to exchange rate shocks, as appreciations of the destination-market 
currency help overcome these fixed costs and lead to increases in the number of trade relationships and products traded within existing relationships that will endure even after the exchange rate shock has dissipated.

The model is partial equilibrium, and the simulations are conducted by solving the static equilibrium in each period given different values of the exchange rate. This approach has the necessary components to explore the short-run response of firms to exchange rate shocks, while maintaining tractability. The long-run effects are inferred based on the existence of the fixed costs and the fact that the data suggest that the long-run effects coming from adjustments in the buyer-seller and product extensive margins are, in part, driven by the accumulation of cohorts of new relationships and products. So, even a transitory shock to the exchange rate can have longrun effects, and exchange rate shocks with any degree of persistence will have larger long-run effects. 


\section{References}

Amiti, M., O. Itskhoki and J. Konings (2014): "Importers, Exporters and Exchange Rate Disconnect," American Economic Review 104(7), 1942-1978.

Arkolakis, C., S. Ganapati and M-A Muendler (2019): "The Extensive Margin of Exporting Products: A Firm-Level Analysis," Working paper.

Auer, R. and R. Schoenle (2016): "Market Structure and Exchange Rate Pass-Through," Journal of International Economics 98, 60-77.

Baldwin, R. (1988): "Hsyteresis in Import prices: The Beachhead Effect," American Economic Review 78(4), 773-785.

Baldwin, R. and P. Krugman (1989): "Persistent Trade Effects of Large Exchange Rate Shocks," Quarterly Journal of Economics 104(4), 635-654.

Berman, N., P. Martin and T. Mayer (2012): "How Do Different Exporters React to Exchange Rate Changes? Theory, Empirics and Aggregate Implications," Quarterly Journal of Economics 127(1), 437-492.

Bernard, A., J. Jensen, S. Redding and P. Schott (2009): "The Margins of U.S. Trade," American Economic Review 99(2), 487-493.

Bernard, A., S. Redding and P. Schott (2011): "Multi-Product Firms and Trade Liberalization," Quarterly Journal of Economics 126(3), 1271-1318.

Bernard, A., A. Moxnes and K. Ulltveit-Moe (2018): "Two-Sided Heterogeneity and Trade," Review of Economics and Statistics 100(3), 424-439.

Blum, B., S. Claro and I. Horstmann (2010): "Facts and Figures on Intermediated Trade," American Economic Review: Papers 63 Proceedings 100, 419-423.

Broda, C. and D. Weinstein (2006): "Globalization and the Gains from Variety," Quarterly Journal of Economics 121(2), 541-585.

Chaney, T. (2008): "Distorted Gravity: The Intensive and Extensive Margins of International Trade," American Economic Review 98(4), 1707-1721.

Devereux, M., W. Dong and B. Tomlin (2017): "Importers and Exporters in Exchange Rate Pass-Through and Currency Invoicing," Journal of International Economics 105, 187-204.

Dixit, A. (1989): "Hysteresis, Import Penetration, and Exchange Rate Pass-Through," Quarterly Journal of Economics 104(2), 205-228. 
Drozd, L., S. Kolbin and J. Nosal (2017): "Long-Run Trade Elasticity and the Trade-Comovement Puzzle," Working Papers 17-42, Federal Reserve Bank of Philadelphia.

Eaton, J., S. Kortum and F. Kramarz (2004): "Dissecting Trade: Firms, Industries and Export Destinations," American Economic Review 94(2), 150-154.

Eaton, J., S. Kortum and F. Kramarz (2011): "An Anatomy of International Trade: Evidence from French Firms," Econometrica 79(5), 1453-1498.

Eaton, J., D. Jinkins, J. Tybout and D. Xu (2016): "Two-Sided Search in International Markets," working paper (October 2016).

Eckel, C. and P. Neary (2010): "Multi-product Firms and Flexible Manufacturing in the Global Economy," Review of Economic Studies, 77 (1), 188217.

Feenstra, R., J. Gagnon and M. Knetter (1996): "Market Share and Exchange Rate PassThrough in World Automobile Trade," Journal of International Economics 40, 187-207.

Feenstra, R., P. Luck, M. Obstfeld and K. Russ (2018): "In Search of the Armington Elasticity," Review of Economics and Statistics 100(1), 135-150.

Fernandes, A., P. Klenow, S. Meleshchuk, M. Pierola and A. Rodriguez-Clare (2018): "The Intensive Margin in Trade," NBER Working Paper 25195.

Garetto, S. (2016): "Firms' Heterogeneity, Incomplete Information, and Pass-Through," Journal of International Economics 101(2), 168-179.

Heise, S. (2018): "Firm-to-Firm Relationships and the Pass-Through of Shocks: Theory and Evidence," SSRN Working Paper No. 2898148.

Helpman, E., M. Melitz and Y. Rubinstein (2008): "Estimating Trade Flows: Trading Partners and Trading Volumes," Quarterly Journal of Economics 123(2), 441-487.

Kramarz, F., J. Martin and I. Mejean (2016): "Volatility in the Small and in the Large: The Lack of Diversification in International Trade," CEPR Discussion Paper 11534 (September).

Krugman, P. (1979): "Increasing Returns, Monopolistic Competition, and International Trade," Journal of International Economics 9(4), 469-479.

Melitz, M. (2003): "The Impact of Trade on Intra-Industry Reallocations and Aggregate Industry Productivity," Econometrica 71(6), 1695-1725.

Melitz, M. and S. Redding (2015): "New Trade Models, New Welfare Implications," American Economic Review 105(3), 1105-1146. 
Monarch, R. and T. Schmidt-Eisenlohr (2017): "Learning and the Value of Trade Relationships," International Finance Discussion Papers 1218, Board of Governors of the Federal Reserve System.

Nigai, S. (2017): "A Tale of Two Tails: productivity Distribution and the Gains from Trade," Journal of International Economics 104, 44-62

Ruhl, K. (2008): "The International Elasticity Puzzle," mimeo. 